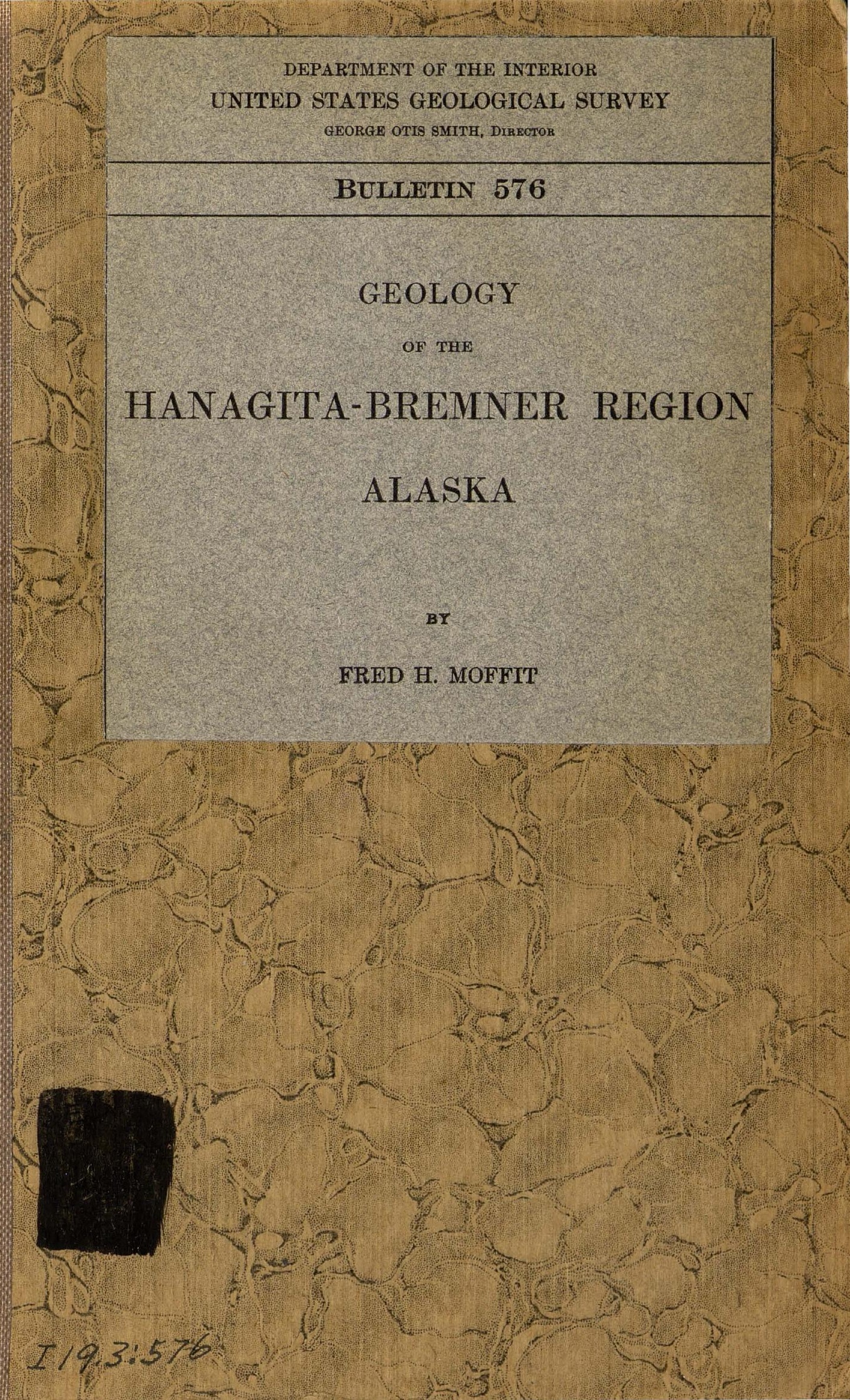



DEPARTMENT OF THE INTERIOR

UNITED STATES GEOLOGICAL SURVEY

GEORGE OTIS SMITH, DIRECTOR

BULLETIN 576

\title{
GEOLOGY
}

OF THE

\section{HANAGITA-BREMNER REGION}

\author{
ALASKA
}

BY

FRED H. MOFFIT

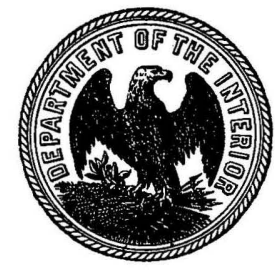

WASHINGTON

GOVERNMENT PRINTING OFFIOE

1914 



\section{CONTENTS.}

Page.

Introduction................................................. 7

Geography............................................ 8

Location and area......................................... 8

Topography........................................... 8

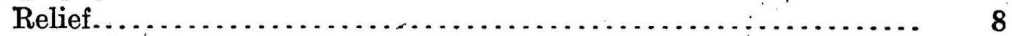

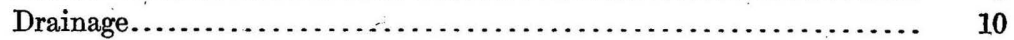

Climate............................................... 12

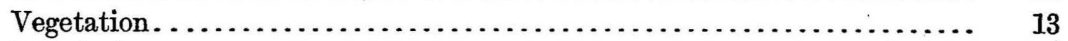

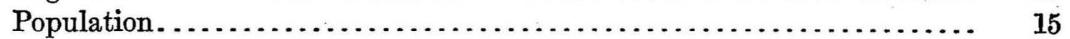

Trails and transportation....................................... 15

General geology ........................................... 17

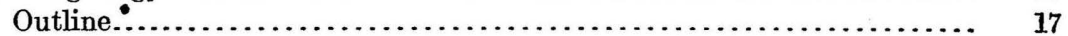

Carboniferous (?) rocks......................................... 18

Character and distribution............................. 18

Age and correlation. ................................. 20

Mesozoic rocks........................................ 21

Subdivisions........................................ 21

Early Mesozoic (?) rocks (Valdez group) $\ldots \ldots \ldots \ldots \ldots \ldots \ldots \ldots \ldots .22$

Character and distribution............................. $\quad 22$

Age and correlation. . . . . . . . . . . .

Middle Jurassic rocks.................................. 25

Character and distribution............................. $\quad 25$

Age and correlation.................................. 26

Quaternary deposits, by Theodore Chapin................... 27

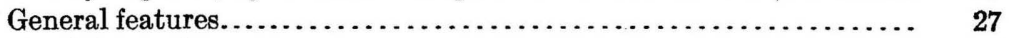

Glacial deposits.................................... $\quad 28$

Gravels. :..................................... 28

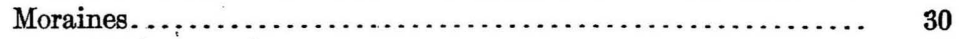

Stream and lake gravels................................. $\quad 30$

Eolian deposits. ...................................... 31

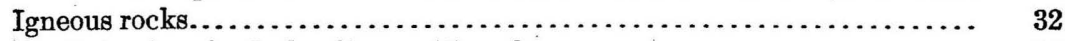

Intrusives in Carboniferous (?) rocks. . . . . . . . . . . $32 \ldots \ldots \ldots \ldots, \quad 32$

Intrusives in slates and graywackes of the Valdez group.......... 34

Intrusives in Middle Jurassic rocks.......................... 34

Age of the intrusives...................................... 35

Structure..................................................... 35

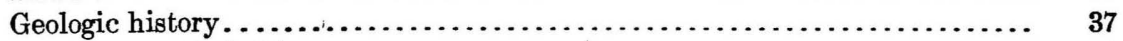

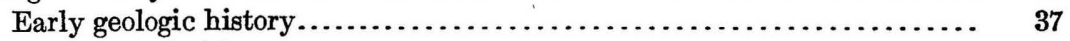

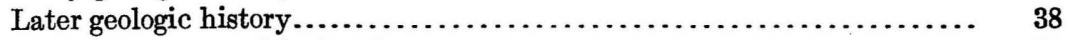

Early topographic development........................... 38

Glaciation........................................... 39

Advance of the ice.................................. $\quad 39$

Retreat of the ice................................... 41 


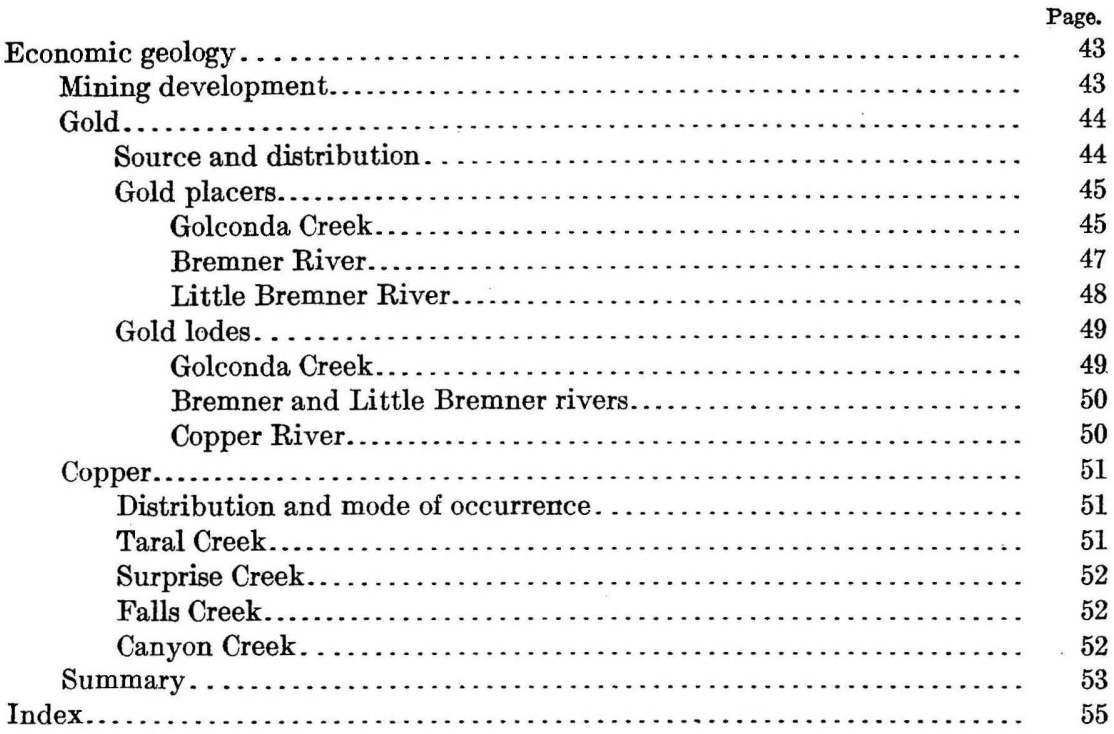

\section{ILLUSTRATIONS.}

Plate I. Topographic reconnaissance map of Chitina quadrangle....... In pocket.

II. Geologic reconnaissance map of Bremner River and Hanagita Val-

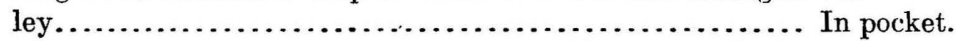

III. $A$, View eastward across Copper River from ridge east of Chitina; $B$, View southward across Tebay Lake ........................

IV. $A$, Top of ridge between Hanagita Valley and Chitina River; $B$, Limestone included in greenstone north of Canyon Creek and west of trail leading from Canyon Creek to Taral; $C$, Bowlder of gneiss on Tebay River................................... 32

V. East end of Hanagita Valley ......................... 40

VI. $A$, View eastward in Hanagita Valley from Sangaina Creek; $B$, Hanging valley on south side of Hanagita Valley near head of Hanagita Creek.

Figure 1. Map of Copper River drainage basin, showing position of Bremner River and Hanagita Valley

2. Map showing distribution of timber in Hanagita and Bremner River valleys.

3. Diagrammatic columnar section showing stratigraphic relations of sedimentary beds exposed in Hanagita and Bremner River valleys.

4. Sketch of greenstone intrusive in conglomerate on east side $f$ Copper River near Taral.

5. Diagram illustrating the formation of a stream channel transverse to a mountain slope at the margin of a glacier. . . . . . . . . . .

6. Diagram illustrating one method of formation of a canyon and a gravel-filled basin on a glacial stream 


\section{PREFACE.}

\section{By Alfred H. Brooks.}

This volume presents information about a region that was little known prior to 1911. A Geological Survey party had indeed hastily examined its northern part in 1900 (see p. 7) but had been able to obtain little except geographic data, and so far as known no other explorations have been made.

Mr. Moffit's survey, though also of a reconnaissance character, was sufficiently detailed to outline the larger stratigraphic units and to obtain much information about the occurrence and distribution of the gold and the copper deposits. The Hanagita-Bremner region includes some mineral deposits which, though almost undeveloped, give promise of becoming commercially valuable now that they have been made comparatively accessible by the railroad recently completed up the Copper River valley.

The results of the investigation have an important bearing on the larger geologic problems of the Prince William Sound-Copper River region. Mr. Moffit has found a series of metamorphic rocks, including some Carboniferous limestones, unconformably overlain by a great thickness of slates and graywackes, which he correlates with the Valdez group of Prince William Sound. Mr. Moffit's work tends to indicate that the Valdez group of sediments is of Mesozoic age. The copper deposits of the region occur in sheared greenstones and therefore resemble those of the Nikolai greenstone of the Tonsina-Chitina district, farther north.

It is proposed eventually to bring together the results obtained in various parts of the lower Copper River basin in one report, which will include a geologic map of the entire district. This, however, must bə preceded by a more detailed study of many parts of the region. In conformity with this plan a detailed geologic study of the western end of the Kotsina-Chitina copper belt was made in 1912. 



\section{GEOLOGY OF THE HANAGITA-BREMNER REGION, ALASKA. ${ }^{1}$}

By Fred H. Moffit.

\section{INTRODUCTION.}

This paper gives an account of the mineral resources and principal geologic features of the Hanagita and Bremner River valleys, so far as they are now known. Hanagita Valley is the name applied to a well-defined topographic depression which lies south of Chitina River, a tributary of Copper River, and is occupied by several streams, of which Hanagita Creek is the largest. The valley takes its name from Hanagita, who was formerly chief of the Taral Indians. Bremner River, which lies south of the Hanagita Valley, is the largest tributary to Copper River between Chitina River and the coast. These two valleys are walled in by rugged mountains belonging to the Chugach Range. Until recently the district, especially the part including the Bremner Valley, was difficult of access and was less known than most other parts of the Copper River basin, but the construction of a railroad up Copper River has put an end to many of the difficulties formerly met by prospectors and explorers.

The Hanagita Valley was visited by a-United States Geological Survey party late in the fall of 1900 , at the close of a season devoted chiefly to the study of the copper belt on the north side of the Chitina Valley. A few geologic observations were made by A. C. Spencer, ${ }^{2}$ and a topographic reconnaissance map prepared by D. C. Witherspoon, which, though made under trying conditions arising from bad weather and lack of supplies, has since proved to be remarkably good.

Previous to this work practically all knowledge of Bremner River had been confined to a small number of prospectors, whose information, although valuable, is not available for public use.

These were the conditions when the surveys of 1911 were undertaken. Two parties, one topographic and the other geologic, were sent into the field. The first, under Mr. Witherspoon, remapped Hanagita Valley and surveyed in addition most of the Bremner and Little Bremner drainage basins. The second party, in charge of the writer, assisted by Theodore Chapin, visited the copper prospects and gold placers and studied the geology of adjacent areas. In all

1 A résumé of this paper was published in U. S. Geol. Survey Bull. 520, pp. 93-104, 1912.

2 Schrader, F. C., and Spencer, A. C., The geology and mineral resources of a portion of the Copper River district, Alaska: U. S. Geol. Survey special publication, 1901. 
about 80 days were given to this geologic reconnaissance. The work was carried on in unusually favorable weather, but was much hindered in Bremner River valley by difficulties of travel. Soft ground, such as is common in many other parts of the Copper River basin, was encountered in few places, and firm footing for horses was found nearly everywhere except on the bars of the lower river, which were carefully avoided. Travel, however, was greatly obstructed by the dense growth of timber and underbrush that cover most of the valley; and although progress of the pack train down Bremner River was greatly aided by the existence of an old and little-used trail, much time, that ordinarily would have been given to geologic work, had to be spent by members of the party in clearing out the trail or cutting new pathways.

Acknowledgment is made to Mr. Ed. Sellers, manager of the Golconda Mining Co., and to Messrs. Wahn and Stone, of Little Bremner River, for their kindness in helping the party to replace a pack load of provisions lost in crossing Sangaina River, and to other prospectors for information of all kinds concerning the district. The writer also wished to acknowledge his indebtedness to Mr. Chapin for assistance in the field and in the office in the work of preparing the maps and studying the rock specimens collected and in criticizing and correcting this paper. Mr. Chapin also prepared the part of the paper dealing with the Quaternary deposits of the region.

\section{GEOGRAPHY.}

\section{LOCATION AND AREA.}

The district here designated by the names of the Bremner River ${ }^{1}$ and Hanagita valleys lies in the southern part of the Copper River drainage basin (fig. 1) and is included within a quadrangle formed by meridians $143^{\circ}$ and $145^{\circ}$ west longitude and by parallels $60^{\circ} 50^{\prime}$ and $61^{\circ} 30^{\prime}$ north latitude. About half of this quadrangle, or 1,500 square miles, was surveyed in 1911. This district lies east of Copper River and extends about halfway from Chitina River to the coast. Its nearest seaports are Cordova and Valdez.

\section{TOPOGRAPHY.}

Relief.-The Hanagita-Bremner region (see Pl. I, in pocket) is part of the Chugach Range, and therefore has a rugged topography. Its relief varies greatly, as is shown by the difference of more than 8,300 feet between the altitude of Copper River at the mouth of Bremner River (200 feet) and that of Hanagita Peak (8,538 feet) near the head of Chakina River. The average elevation of the mountain tops, however, probably lies between 6,000 and 7,000 feet, and the

1 Lieut. Henry T. Allen (Report of an expedition to the Copper, Tanana, and Koyukuk rivers, in the Territory of Alaska, in the year 1885, p. 48,1887) gives the native name of Bremner River as Tetahena. 
elevations of the main valleys are considerably yreater than that of Copper River, which at Taral is 450 feet above sea level, or 250 feet above the mouth of Bremner River. South and east of Bremner River the mountains reach much greater heights, especially in the region toward Mount St. Elias, where they stand like islands in a vast snow field.

The Hanagita Valley, from the head of Canyon Creek to Klu River, preserves a fairly uniform elevation of 2,500 to 3,000 feet above

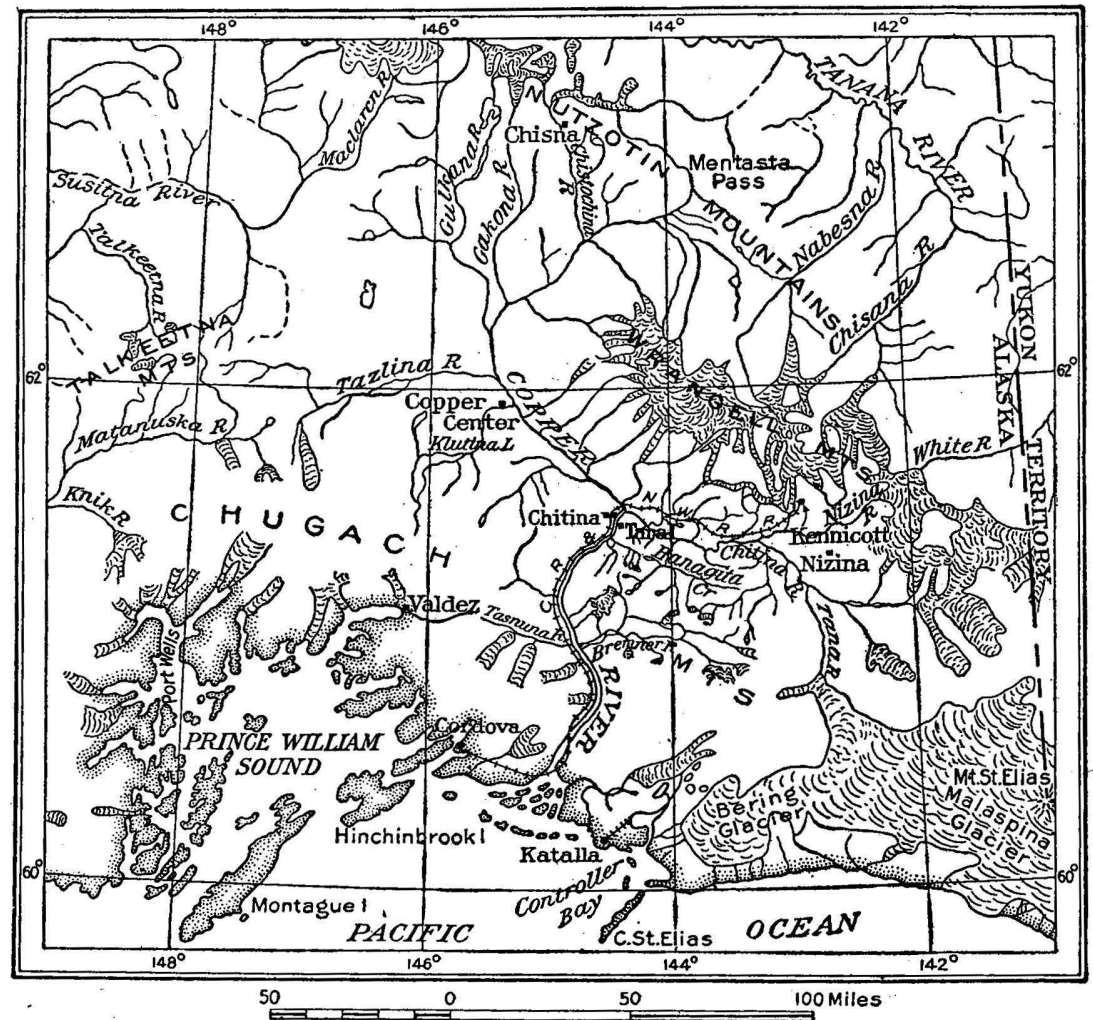

FIGURE 1.-Map of Copper River drainage basin, showing the position of Bremner River and Hanagita valley.

the sea, or practically that of timber line in this region, this uniformity being interrupted, however, at Tebay River, where the elevation decreases to 2,000 feet, and at the mouth of Canyon Creek. The broad pass occupied by the Tebay Lakes, between the Hanagita Valley and Little Bremner River, has an elevation of 1,800 to 1,900 feet above the sea. In contrast with these higher valleys the main valley of Bremner River stands less than 1,000 feet above the sea. The relief is therefore greater in the Bremner River valley than in the Hanagita Valley. 
To a trained eye the most conspicuous topographic characteristic of this whole district is its universal and profound glaciation, as expressed chiefly in the straightened walls and broad U-shaped cross sections of its valleys (Pl.VI, $A$, p. 41) and less strongly by the rounded knobs of bare rock (roches moutonnées), which are particularly noticeable in the upper valley of Tebay River (Pl. III, $B$, p. 28), and by the steep cirque walls at the heads of valleys. The broad, flat mountain tops on both sides of Copper River near Taral, north of the upper part of Canyon Creek, and in a few other places, are believed to be further evidences of the same action, although they may perhaps be ascribed to an earlier cycle of erosion. Glaciation has thus been the chief agent in giving the topography of this district its present ruggedness.

A marked difference exists between the appearance of the mountains north of the Hanagita Valley and those inclosing Bremner River. The mountains between the Hanagita Valley and Chitina River have a sky line so much more even (Pl. IV, $A$, p. 32) and contours so much smoother than those to the south that the difference immediately strikes the eye. The change from one to the other is, however, gradual, and may possibly have been brought about in part by the slow retreat of the glaciers from the borders of the range toward the center, giving time for ordinary atmospheric weathering to efface some of the smoothing due to glacial erosion. A more important cause, however, is that the ridge north of the Hanagita Valley was, at least in places, actually overridden by the great ice mass moving in the Chitina Valley.

Drainage.-The arrangement of streams in the district is peculiar. (See Pl. I, in pocket.) In general the streams are parallel either with Chitina River or with Copper River, more commonly the former. The Hanagita Valley presents the best example of this arrangement. It is occupied by three principal streams-Canyon Creek, Bridge Creek, and Hanagita Creek-and it extends eastward from Copper River parallel to Chitina River for 50 miles. Bremner River, the upper part of its North Fork, and its large southern tributary show the same parallelism. Tebay River, parts of Little Bremner River, the big bends of Bremner River and of its forks, Golconda Creek, Monahan Creek, and many smaller streams show parallelism to Copper River and are all roughly perpendicular to Chitina River. Bremner and Little Bremner rivers are examples of both arrangements, for although their longer stretches are parallel to Chitina River their offsets are parallel to the Copper. Klu River is the most notable exception to the general system, for its straight parts do not conform to either direction.

Bremner River, including the Little Bremner, drains nearly 1,000 square miles of territory and, next to Chitina River, is the 
largest tributary to Copper River in the southern part of the Copper basin. Most of its important branches originate in glaciers and snow fields, the number and size of which increase toward the south and east till they finally merge into the great coast-range ice cap.

Small boats may be used on Bremner River below North Fork, near the mouth of which is a saw pit where a number of boats have been built. The upper part of the navigable portion of the stream is swift but is without dangerous rapids except at the head of Threemile Canyon. Below Threemile Canyon the grade is slight and the river spreads out, depositing an immense amount of fine quicksand and treacherous mud. Little Bremner River is navigable by small boats to a point about 4 miles from its mouth, but above that point its channel is a succession of rapids and falls through narrow canyons and intervening open stretches of lower grade. North Fork descends from its upper valley to the main Bremner through Twelvemile Canyon, a narrow gorge which is cut several hundred feet into the slate and graywacke at its deepest part but grows shallow toward its head and opens out into a wide valley at its lower end. This canyon is impassable either for boats in summer or for sleds in winter.

Tebay ${ }^{1}$ River drains the Tebay Lakes, but receives most of its water from Hanagita Creek, a much smaller part coming from Bridge Creek, the outlet to Summit Lake. Between the lakes and Bridge Creek the current is slow and the channel deep and meandering, but below Hanagita Creek the river descends 1,000 feet in the stretch of 6 miles to Chitina River. Hanagita Creek is the largest stream in the Hanagita Valley; it drains a number of small lakes and receives water from numerous tributaries. Sangaina Creek is the largest of these tributaries and is well known to the prospector as a dangerous stream because of its swift current and the great number of bowlders in its channel. Canyon Creek, which in the lower 5 miles of its course flows through a deep gorge, has a narrow valley that has been less modified by glacial erosion than the rest of the Hanagita Valley. Klu River, which crosses the eastern end of the Hanagita Valley, is the principal branch of Chakina River. Its channel across the valley and for a short distance above is very crooked, though not so meandering nor so sluggish as the corresponding part of Tebay River. Like Tebay River, its grade and its velocity increase immediately after crossing the Hanagita Valley.

Nearly all the streams of the district flow over broad gravel flats in their upper courses and through narrow rock-walled canyons in their lower courses - a feature common to the recently glaciated valleys of Copper River basin and the result of an effort by the 
streams to readjust grades that have been disturbed by glacial erosion. On some streams, like Little Bremner River, the succession of gravel flat and canyon is several times repeated.

Small lakes are numerous in the Hanagita and Bremner valleys. Most of them result from imperfect drainage due to glacial erosion or to glacial deposition, though many of the smaller ones have been formed by beavers. The Tebay Lakes are two beautiful bodies of water and are the largest in the district. They differ little in elevation, yet the lower one is surrounded by timber and the upper and smaller one is above timber line. Summit.Lake is also above timber line, and was still partly covered with ice at the end of June, 1911. Some of these lakes, such as the smaller Tebay Lake, might become valuable sources of water power.

\section{CLIMATE.}

Few weather observations for the district are on record and the climatic conditions can be described only in general terms, based principally on the experience of prospectors and of the Geological Survey parties in 1911, nor can much dependence be placed on observations made in neighboring localities, for considerable differences may exist between places very close together, a fact that explains many apparent discrepancies in different accounts.

Bremner River is separated from the Pacific Ocean by high snow-covered mountains on which much of the moisture carried by the ocean winds is precipitated before it can reach the interior. In consequence, though the seaward side of the Chugach Range is a region of great precipitation, the interior Copper Basin receives only moderate precipitation. In spring and early summer the moisture is sufficient to support a flourishing vegetation, but by the middle of August the grass dries up in many places and settlers and prospectors are obliged to irrigate their gardens. In the Bremner River and Hanagita valleys intermediate conditions prevail.

The lower Copper River valley is the only break through the Coast Range between Cook Inlet and Alsek River, and its depression is too narrow to permit free access of the moisture-laden air currents to the interior. There are, however, strong winds up Copper River in summer and down it in winter, and in both summer and winter the part of the river below the Tiekel is subject to heavy precipitation and to severe storms. The country adjacent to the Copper River valley is influenced by these conditions. Along Little Bremner River and on the lower part of Bremner River, according to the reports of prospectors, there are a greater number of rainy and cloudy days than on the upper Bremner. The same is probably true of the Hanagita Valley. In both valleys the summer weather is distinctly pleasant. 
The snows are heavy and in high valleys like the Hanagita are likely to remain until late, in the spring, in some seasons well into June or even July. Minimum temperatures of $40^{\circ}$ to $50^{\circ}$ below zero are reached in winter, but the extreme temperatures of the upper Copper Basin and of the Yukon Valley are probably never attained.

\section{VEGETATION.}

Spruce, the only valuable timber in either of the two valleys, is found in varying amount and quality in both. Timber line averages about 2,500 feet above the sea, but in places reaches 3,000 feet. It is likely to be a little higher in the east-west than in the north-south valleys, probably because the former are protected from the strong winds and because they profit more by the direct rays of the sun. Spruce of fair quality grows about Taral, on Canyon Creek, and on Tebay River. (See fig. 2.) Most of the timber between Bridge Creek and the Tebay Lakes has been burned, however, leaving only bare rocky knobs on which a growth of small willow has sprung up. A scattering growth of spruce is found about the larger lake, but does not extend to the upper lake. Summit Lake is above timber line, and most of Hanagita Creek is only a short distance below it. Spruce grows in scattered patches (Pl. V, p. 40) on both sides of the Hanagita Valley, avoiding as a rule the lower marshy central part. The best timber in Hanagita Valley is found between Klu River and Monahan Creek and thence eastward to Chakina River. Some fine trees over 2 feet in diameter were seen on the north side of this valley east of the little lake. Trees of poorer quality extend up Monahan Creek to a point within a mile of the pass to Golconda Creek. A heavy growth of spruce covers the lower slopes of the mountains south of Chitina River, but the wood is brittle, and would yield only a poor grade of lumber. There is no spruce on Copper River south of the Tiekel.

Bremner River valley is much lower than Hanagita Valley and most of it, from the mouth to within a few miles of the glaciers at the heads of its larger branches, is covered with a thick growth of spruce. Much of this timber is large and of excellent quality, but a great deal of it has been killed or made valueless by fires set to rid the country of mosquitoes and flies. The dead timber stands till the roots have rotted and then falls in a tangled mass that is extremely difficult to traverse, the difficulties usually being increased by a dense growth of small willow, which starts as soon as fire has destroyed the moss and stripped the trees of their leaves.

Some of the finest spruce in the Copper River basin grows in the lower part of the valley of Little Bremner River. Timber extends up the valley to a point within a mile or two of Little Bremner Glacier, although it becomes smaller and more scattered in the northern part near timber line. Its absence along the stream below the 
glacier is due to the fact that the ice vacated this part of the valley too recently to give time for the growth of spruce, rather than to the altitude, for trees grow near by at higher elevations. Fires have not done so much damage in this valley as along the main Bremner.

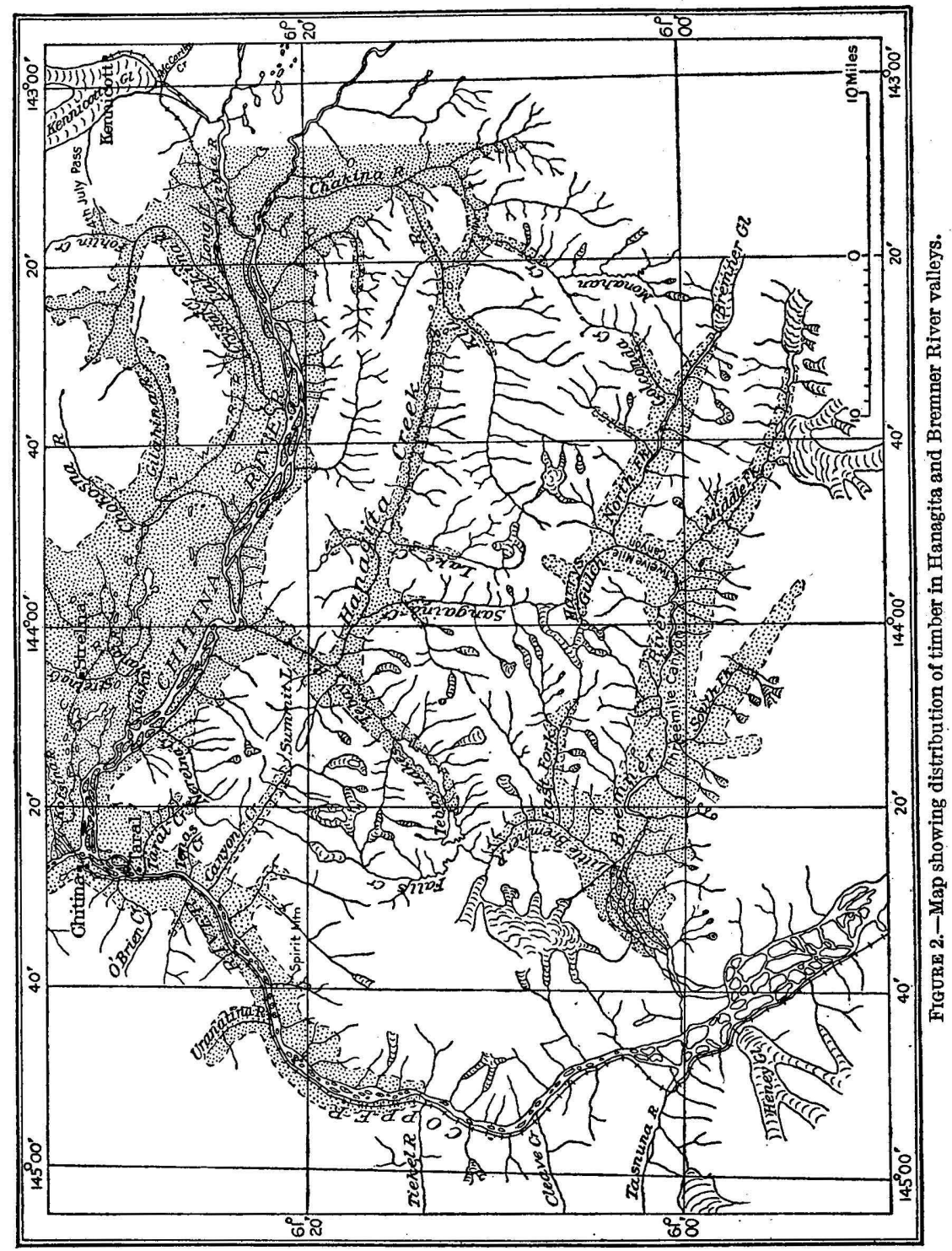

The mountain slopes of the Bremner and Little Bremner valleys are covered to a considerable height above timber line by a heavy growth of alder, which makes climbing extremely difficult and tiresome and in many places renders it impossible to travel with a pack horse without first clearing a trail. In favorable localities the alder 
grows to a height of 12 to 15 feet, but the trunks, instead of standing erect, run along or near the ground, all commonly leaning in the same general direction. Those that grow on slopes lean downhill, being bent that way by the weight of snow that covers them during much of the year, but even those growing on a level show the same attitude and parallelism of trunks. The alders not only obstruct travel but hide outcrops and thus make prospecting difficult. Fortunately moss is not so plentiful in this region as in many other parts of Alaska, particularly along the Pacific coast, where the heavy precipitation is especially favorable to its growth. The devil's club, however, is common, and commands respect from those who have had experience with it.

Grass for horses is plentiful in nearly all parts of the Hanagita and Bremner valleys. Its growth is scant in some of the timbered valley bottoms, but it grows luxuriantly on the upper hill slopes near timber line. Bunch grass and redtop are the more common grasses, the first being found throughout the Hanagita Valley and sparingly on Bremner River, where the second prevails. Bunch grass does not grow so luxuriantly as redtop, but it cures early on the stalk and is less affected by the first frosts, and is consequently available for feed much later in the fall. Grass is found in parts of the district from late May or early June until the middle of September or first of October.

\section{POPULATION.}

There is no permanent white population east of Copper River in the district, but for many years there has been at Taral an Indian village consisting of 10 or 12 houses occupied by as many or more families. During the summer of 1911,20 to 25 miners and prospectors were scattered through the two valleys: Three on Little Bremner River, three on Bremner River, seven on Golconda Creek, two on Klu River, and the rest in the vicinity of Taral and Canyon Creek. No attempt was made to count the Indians, who, during the summer, are scattered along the river at numerous fishing stations. Their chief is Goodlata, the son of Chief Nikolai, and an Indian of exceptional ability.

\section{TRAIIS AND TRANSPORTATION.}

No trails have yet been well established through either the Hanagita or the Bremner River valley. The travel of white men there has been light and irregular, and the natives, notwithstanding the fact that they have passed back and forth in Hanagita Valley for many years, have not managed to establish a well-marked and continuous trail. In places distinct and unmistakable stretches of trail are found, but between them every man has chosen his own way. The route now followed starts at Taral, ascends Taral Creek to the lakes near its head, turns south to Canyon Creek, and then leads eastward through the valley to Chakina River. Five miles of this trail 
between Taral and the head of Taral Creek was made as assessment work on a copper claim. It is steep but good, as is also the remainder to Canyon Creek, except about 2 miles of swampy ground on the summit between the lakes and Divide Creek. Through nearly all the Hanagita Valley travel is good except at the crossing of Sangaina Creek, a swift glacier stream flowing in a channel filled with large bowlders. In times of high water, notably at the end of warm summer days when the glaciers are discharging a large amount of water, horses have hard work to keep their feet while fording this stream and if once down have little chance of getting out.

Late in the fall of 1911 a new trail down Canyon Creek to Copper River was built for use in the winter freighting of supplies to the copper properties at the head of Canyon Creek. It avoids the steep hills of the older route and should considerably reduce the cost of freighting.

A trail up Monahan Creek and over the divide to Golconda Creek is used in both winter and summer. In most parts it is poor and it is interrupted in several places by newly formed beaver ponds.

In 1907 Decker and Mayman, owners of the placer claims on Golconda Creek, cut a trail down the north side of Bremner River from a point a short distance above the mouth of Golconda Creek to a point on Little Bremner River, 4 miles above its mouth. It was expected that the miners on the lower part of Bremner River would continue it to Copper River, but they failed to do so and it soon became overgrown with brush and blocked by fallen trees. In 1911 the Geological Survey parties cleared much of it and provided ways past several talus slides and bad places along the river so that at present this trail is in fair condition, for it was laid out over good. firm ground. When it comes to be used more frequently easier slopes will be chosen to avoid several steep hills.

A trail that has been used much by foot travelers leads up Little Bremner River from the mouth of that stream to its head, but until 1911 this trail was impassable for horses at its upper end. A few days' work made it possible to take horses from the Little Bremner to Hanagita Valley by way of Tebay River, and if travel in this direction continues, a good trail can be established.

The problem of freight transportation into this region has been transformed by the completion of the railroad up Copper River. Where it was formerly necessary to carry supplies by sled over a long and difficult road before reaching the outskirts of the region it is now possible to place them by train within a comparatively short distance of their destination. Supplies for the lower part of Bremner River and the Little Bremner are landed near the mouth of Tasnuna River and carried on the river ice to the different camps. Prospectors near Taral get them at whatever point on the railroad may be most convenient-Chitina, Taral, or the mouth of Canyon Creek. The pros- 
pectors and miners on Klu River and Golconda Creek ship their supplies and mining equipment to a point near the mouth of Nizina River, whence they are carried by sled up Chitina and Chakina rivers to Monahan Creek and thence to Klu River or over the divide to the gold placers of the Golconda. It will thus be seen that apart from the railroad freight charges, the cost of freighting to these three areas differs widely, being least to Bremner River and greatest to Golconda Creek. The cost of freighting to Golconda Creek was not learned, but any considerable quantity of freight could probably be landed there for 5 cents or less per pound, exclusive of railroad charges.

\section{GENERAL GEOLOGY.}

\section{OUTLINE.}

The general distribution of the principal formations of the Hanagita and Bremner River valleys is shown on the geologic map (Pl. II, in pocket) and their stratigraphic relations are represented in figure 3.

Two groups of sedimentary rocks occupy most of the area under consideration. The oldest consists of schist, slate, and limestone, which form the chief rocks of the mountains between the Hanagita Valley and Chitina River and of those south of the Hanagita Valley eastward from Copper River for nearly 30 miles. These sedimentary beds are folded, faulted, and much metamorphosed. Furthermore, they are intruded in a most complicated manner by igneous dikes and sills, which are chiefly dioritic, but include granitoid rocks of a more basic kind. A few Carboniferous fossils were found at one locality, but the group is based on structural and stratigraphic rather than on paleontologic evidence.

The second group of sedimentary beds consists of interstratified slate

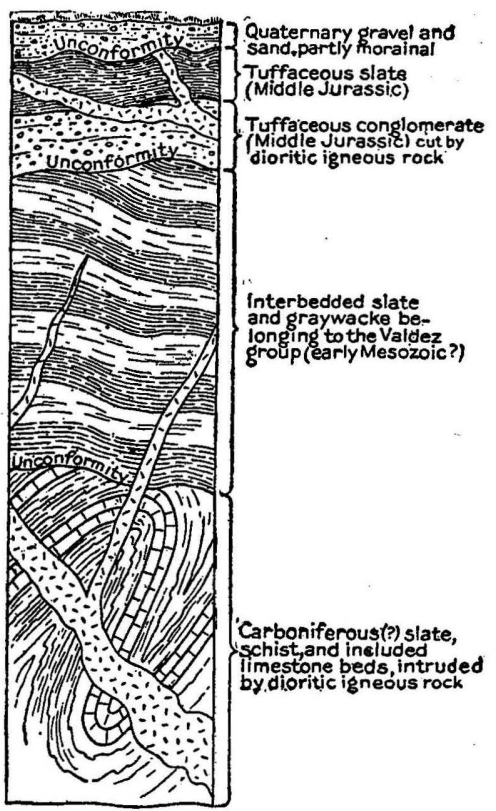

FIGURE 3.-Diagrammatic columnar section showing stratigraphic relations of the sedimentary beds exposed in the Hanagita and Bremner River valleys. and graywacke, here classed as early Mesozoic (?) (Valdez group). ${ }^{1}$ It adjoins the group first mentioned on the south and is exposed

1 The work of Johnson in Prince William Sound during 1912 and 1913 has shown that some of the rocks included by previous workers in the Valdez and Sunrise groups are of Jurassic age. Martin, on the other hand, finds evidence in southwestern Kenai Peninsula indicating that part of the Sunrise group may be Paleozoic. 
throughout the valley of Bremner River and in the mountains south of the east end of the Hanagita Valley. These sedimentary rocks are folded and faulted, but are less metamorphosed than the schist and limestone beds bounding them on the north. They are cut by numerous light-colored dikes of quartz monzonite. The contact relation between the two groups of sedimentary formations is somewhat in doubt, but it is probable that the slate and graywacke were deposited unconformably upon the schist, slate, and limestone beds. (See Pl. II, in pocket.)

A third group of sedimentary rocks, of small extent so far as present information goes, is exposed in the vicinity of Taral. This group includes massive tuffaceous conglomerate, tuffaceous slate, and probably also some small isolated areas of sandstone. It is intruded by dikes and irregular-shaped masses of more or less altered diorite and diabase. The conglomerate and tuff beds are folded and faulted, but in general they appear to be less altered than the rocks of the two larger groups. Fossils collected from the tuff beds indicate a Middle Jurassic age for this group. From evidence obtained in other districts it is believed that the Jurassic beds rest unconformably upon the underlying sediments, but it is highly probable that in the vicinity of Taral the contact relation is complicated by faulting.

Igneous rocks are common throughout this district. Diorite and closely related types are the most common, but more basic intrusives are found in several places. The dioritic rocks doubtless belong to several periods of intrusion. Some of them are light colored, coarse grained, and almost unaltered; others are fine grained and dark colored. Diorite is especially common in the vicinity of Taral and is in places so greatly altered that it can not be readily distinguished from the altered diabase associated with it. The greenstone so abundant east of Taral is derived from diorite and diabase. A few very basic dikes having the composition of peridotites were found in this vicinity.

The Quaternary deposits of the district include unconsolidated stream and lake deposits and morainal material left by the glaciers. They are distributed throughout the whole area mapped. Windblown sand forms deposits of considerable amount along Copper River, especially in the vicinity of Chitina.

\section{CARBONIFEROUS (?) ROCKS.}

Character and distribution.-The age of the rocks here tentatively referred to the Carboniferous system is not yet well established. The group consists of interstratified schist, slate, and limestone beds, readily distinguished from the succession of sediments bounding it on the south and from the Jurassic conglomerate and tuff beds near Taral. It is here regarded as a unit which might be subdivided in 
detailed mapping and which may later be found to contain deposits of other than Carboniferous age, though no evidence indicating this has yet been obtained. The group consists essentially of schist and slate, but contains many beds of limestone, one or two of which are several hundred feet thick.

The schist and slate beds show considerable variation in appearance. Their colors range from silvery gray to green and black, depending on the character of the original sediment and the amount of metamorphism the rocks have undergone. Local differences appear also in the degree of alteration, and on these the distinction between slate and schist probably in large part depends. A welldeveloped cleavage is found nearly everywhere, but in many places the rocks have become highly fissile and show marked development of mica and chlorite. The limestone beds are recrystallized and locally are highly silicified as a result of their intrusion by igneous bodies.

The boundary between the Carboniferous (?) sedimentary beds of the Hanagita Valley and the slate-graywacke area to the south is marked by a narrow belt probably only a few hundred feet wide of dense, hard, reddish altered diabase. This rock was found near the boundary at many places between Tebay River and Monahan Creek, but was not seen on Copper River. A similar rock outcrops on Hanagita Creek a few miles east of Tebay River. It is seemingly out of its proper place on Hanagita Creek and suggests that the diabase is either intruded into the schist or that it reached its present position through faulting. Although the red rock was seen in numerous places along the boundary, no favorable place was found for determining its structural relation to the rocks on each side of it. It is mapped with the Carboniferous schist on the evidence of the similar rock on Hanagita Creek, but whether it is a mass intruded along the boundary line or is a surface flow poured out on the older rocks is a problem that can not be solved with the evidence at hand.

The members of this group of Carboniferous (?) rocks are closely folded and much faulted. Faulting is best recognized where it involves the limestone beds and is so general throughout the district that none of those beds is now continuous for considerable distances, though many of them, now broken into isolated limestone masses, are evidently parts of a once continuous bed.

In addition to the changes brought about by close folding, extensive faulting, and the other physical and chemical alterations attending these changes, the Carboniferous (?) rocks have been profoundly altered locally by intrusions of igneous rock. This alteration is greatest near Tebay River, where the intrusive and its host are so intimately associated and so extensively metamorphosed that the whole has been changed to a banded gneiss. (See Pl. IV, C, p, 32.) 
The Carboniferous (?) sedimentary beds are the prevailing rocks of the mountains on both sides of the Hanagita Valley, except in the vicinity of Klu River and Monahan Creek (see Pl. II, in pocket), and in a small area near the juncture of Copper and Chitina rivers. Their southern boundary crosses Copper River a short distance north of Tiekel River and extends eastward to the valley of Chakina River, beyond which it has not been traced. It is found on Tebay River near the north end of the larger lake and crosses to the north side of Hanagita Creek not far from Klu River, but immediately swings south again. It thus appears that with the exceptions noted all the mountains between this boundary and Chitina River are made up of rocks belonging to this group. The part of the Chitina Valley between the river and the foothills of the Wrangell Mountains has not been examined and it is not known whether the slate and schist extend that far north, but the appearance of the metamorphic rocks at the mouth of Nizina River indicates that they belong to this group. The same sort of schist and interbedded limestone is present in the vicinity of Kimball Pass on the old Valdez-Fairbanks trail, and the belt probably extends westward beyond that. It would thus include part or all of the amphibolite schist described by Schrader ${ }^{1}$ as occurring on the west side of Copper River between Tonsina River and Wood Canyon.

Age and correlation.-The evidence available to 'show the age of the sedimentary formations here provisionally classed as Carboniferous (?) is not conclusive. The fossils collected from them are few and imperfect, and no fossils were found in most of the formations so classed.

Fossils were collected from a highly siliceous thin-bedded limestone exposed on the ridge between Divide and Falls creeks. They appear only on the weathered surface of the limestone and were obtained with considerable difficulty. G. H. Girty, who examined the two lots both collected at the same locality, makes the following report on them:

These collections contain the following:

$11 \mathrm{AC} 40$. Crinoid stems very abundant and some of them very large; other specimens possibly inorganic but having a shape suggesting the genus Productus.

11 AM 43. Crinoid stems very abundant; Zaphrentis? sp. The Zaphrentoid coral appears to be a Paleozoic type; and from the abundance and size of the crinoid stems and the wide distribution of Carboniferous rocks in Alaska it seems probable that the horizon is Carboniferous.

Carboniferous rocks are exposed in the northern part of the Copper River basin along the south flanks of the Alaska Range, where they include the Chisna and Mankomen formations described by Menden-

\footnotetext{
1 Schrader, F. C., A reconnaissance of a part of Prince WVilliam Sound and the Copper River district, Alaska, in 1898: U. S. Geol. Survey Twentieth Ann. Rept., pt. 7, p. 414, 1900.
} 
hall.1 They are also found on the north side of the Wrangell Moun tains from the head of Copper River to White River as well as in many others parts of Alaska, including southeastern Alaska, the upper Yukon and Porcupine valleys, and the Arctic slope. For purposes of comparison, only the Copper River basin and the north slope of the Wrangell Mountains need be considered.

The Chisna formation consists essentially of tuff, quartzite, and conglomerate with associated intrusives. It is nearly everywhere conspicuous because of its red color due to the oxidation of the abundant iron pyrite it contains. A few poorly preserved fossils, mostly crinoid stems, have been collected from thin limestone beds in the formation, which was referred by Mendenhall to the Carboniferous system because, according to his determination, it underlies the undoubtedly Carboniferous Mankomen formation.

The Mankomen formation (Pennsylvanian), as described by Mendenhall, consists of 6,000 to 7,000 feet of tuff, limestone, sandstone, and shale, with diabase intrusives. This series of beds may be separated into two divisions, a lower one, prevailingly arenaceous and tuffaceous, and an upper one, prevailingly calcareous. The Mankomen formation is correlated with the massive limestone at the head of White River. In both these districts numerous fossils have been collected and on their evidence the beds are referred to the Pennsylvanian. The fossils, however, are more closely allied to forms found in the Russian Urals than to those of the Pennsylvanian in the United States.

As the Pennsylvanian sediments are highly fossiliferous in nearly all the known Alaskan localities, it seems probable that the Carboniferous sedimentary beds of the Hanagita Valley are related to the Chisna formation of the upper Copper River valley rather than to the Mankomen formation. Too little is known concerning the age of either the Chisna formation or the rocks of the Hanagita Valley to justify their definitive correlation, yet it appears nrobable that further study may warrant such correlation.

\section{MESOZOIC ROCKS.}

\section{'́UBDIVISIONS.}

The formations here described as Mesozoic rocks include the series of beds of graywacke and slate that are exposed chiefly in the valley. of Bremner River and the small area of Middle Jurassic conglomerate and tuff beds in the vicinity of Taral. The first group represents the eastward extension of the interbedded graywackes and slates forming the mountains about Valdez Bay, called by Schrader ${ }^{2}$ the

\footnotetext{
2 Mendenhall, W. C., Geology of the central Copper River region, Alaska: U. S. Geol. Survey Prof. Paper 41, pp. 33, 40, 1905.

2 Schrader, F. C., op. cit., p. 408.
} 
Valdez series and here termed the "Valdez group." The age of the Valdez group has not yet been fixed, recent work having shown that rocks of widely different age have been included in it; and the age of the graywacke-slate succession has been determined only within wide limits. The beds are therefore referred provisionally to the Mesozoic, with full recognition of the possibility that future work may show that they are in part older.

\section{EARLY MESOZOIC (?) ROCKS (VALDEZ GROUP).}

Character and distribution.-The southern part of the district under consideration is occupied by interstratified beds of slate and graywacke that cover about half the area surveyed in 1911. These beds are less altered than the Carboniferous formations, but in places are so greatly metamorphosed that the rock may be called schist. The slate is fine grained and is greenish or bluish gray to nearly black in color. In places it shows well-developed slaty cleavage, which, however, hardly reaches the degree of perfection found in roofing slates. The graywacke is a sandstone-like rock of gray or bluish color, but it contains less quartz and more feldspar and dark-colored minerals than a typical sandstone. In many places it includes small fragments of slate and shale and might be regarded as a fine-grained conglomerate. The graywacke of the Bremner River district and of the Valdez group generally differs from the slate in having coarser texture and less well-developed cleavage. Freshly broken surfaces of the rock are rough and show plainly its small constituent particles. On account of its jointing and its lack of good cleavage the graywacke, when exposed to sun and frost, tends to break down in blocks rather than in slabs. Graywacke forms a large proportion of the stream wash in areas occupied by this part of the Valdez group, the better cleavage of the slate causing it to be more easily broken up and carried away, leaving the graywacke as a sort of concentrated residual. The alternating beds of slate and graywacke commonly grade into each other, the differences between them having resulted from variations in the coarseness of the sediments of which they are formedvariations probably due largely to changes in the rate of weathering and deposition and in the nearness of the land mass which furnished the material deposited.

The slates and graywackes are folded and considerably metamorphosed, though less so (see p. 19) than the Carboniferous (?) beds. On Monahan Creek and on the upper part of Golconda Creek the beds are practically horizontal, but assume a southerly dip farther south. Similarly the dip of the beds on the lower part of Little Bremner River ranges from $30^{\circ}$ to $40^{\circ} \mathrm{S}$., decreasing toward the north. These figures, for the most part, represent the dip of the cleavage as well as 
that of the bedding, but in many places the two are different and should be carefully distinguished.

The slates and graywackes are intruded by numerous dikes and sills of light-colored porphyritic rocks that are related to the diorites and may be described as quartz monzonite. These intrusives appear to be more common in the vicinity of the boundary between the slate-graywacke group and the Carboniferous (?) beds to the north than they are at a distance from it. The amount of diorite on the gravel bars of Bremner River, however, particularly the north fork, shows that there must be a large area of that rock in the mountains between the Bremner and Tana rivers.

Besides being intruded by numerous dikes, the slates and graywackes are cut by a great number of quartz veins, some of which contain metallic sulphides and a small amount of gold. Most of the quartz veins are small, yet a number are several feet thick. Few of the veins observed have any considerable linear extent and, with some exceptions, they may be classed as gash veins and fillings in openings along joint planes and at the bends of folds. A few veins containing calcite as well as quartz were seen. Quartz veins are associated with many of the dikes, but whether the association is accidental or results from genetic relations was not determined.

Age and correlation.-The character of the rocks belonging to the Valdez group does not appear to be favorable to the preservation of organic remains. Possibly organisms were not plentiful in the waters in which the deposits were laid down, or possibly remains of organisms once present have been destroyed by metamorphism. At any rate only a few imperfect forms have been found, and they are not sufficient to determine the age of the beds except within a wide limit of error. The evidence for the age of these beds therefore is to be found only in their structural relation to beds of known age, in their degrees of metamorphism as compared with that of beds of known age, and in the metamorphism of the igneor's rocks that are intruded into them.

There is little doubt that the slates and graywackes on the north side of Bremnel River are the direct eastward continuation of the same sort of beds exposed about Valdez Bay and along the military road from Valdez to the vicinity of Tiekel River. They were so mapped by Schrader, who traversed the Tasnuna Valley in 1898 and who distinguished them from the similar, widely distributed but younger Orca group in Prince William Sound.

The Orca group consists chiefly of alternating beds of dark-colored slate and graywacke, with numerous intercalated lava flows, now altered to greenstone, in its lower part, and with a subordinate amount of conglomerate and limestone. According to. Grant the 
Orca group lies unconformably upon the Valdez group. Its age is unknown, but Grant concludes ${ }^{1}$ that in the light of our present knowledge that "it is reasonable to regard the Orca group as of Mesozoic and in part probably Jurassic age." 1 Rocks of the Orca group are present on the lower part of Copper River, but it is probable that they do not extend as far north as Bremner and Tasnuna rivers. At any rate they are not recognized north of Tasnuna River, although the railroad cut furnishes a good opportunity for observation.

It is therefore believed that the slates and graywackes of Bremner River are correctly referred to the Valdez group and that the Orca group affords the best criterion now available for determining their upper age limit.

Evidence for the lower age limit of these rocks is less satisfactory. The contact relation between the slates and graywackes of Bremner River and the schists and limestones of the Hanagita Valley is not definitely known. In some places it seems clearly to be one of faulting but in other places it appears more probably to be one of unconformity. No place was found where either group underlies the other, and direct evidence of this kind for their relative stratigraphic positions is lacking.

The slates and graywackes show less folding and less recrystallization than the schists and limestones. Locally, the slate and graywacke show considerable metamorphism and (see p. 22) might even be regarded as schist, yet in general their metamorphism is not so great as that of the other group.

The granular intrusives in these two groups of rocks give valuable aid in determining their relative ages. Such intrusives are more common in the Carboniferous (?) rocks than in the slates and graywackes. In the former their intersecting dikes and their widely different degrees of alteration distinctly show that they belong to two or more periods of intrusion. The.older inirusives are much altered, showing a banded structure and an imperfect cleavage due to shearing and the development of new minerals. The younger intrusives are practically unaliered and appear not to have been subjected to the movements that affected the older rocks.

Light-colored dikes and sills cutting the slates and graywackes are common in the Bremner River district although less so than in the schist of parts of the Hanagita Valley. Many of them were seen near the boundary between the two groups of sedimentary rocks, and they are doubtless more numerous there than at a distance from the boundary. These intrusives show little evidence of movement in the inclosing rock except such as resulted in jointing or faulting

1 Grant, U. S., and Higgins, D. F., Reconnaissance of the geology and mineral resources of Prince William Sound, Alaska: U. S. Geol. Survey Bull. 443, p. 33, 1910. 
of the dikes and sills. Shearing and alteration like that in the older intrusives of the Carboniferous (?) rocks were not seen in the dikes and sills of the slate and graywacke area. This is believed to be significant and to indicate that the older granitoid Carboniferous (?) rocks had been intruded and subjected to disturbing movements before the graywacke-slate beds had been deposited. If this is true, and if the beds referred to the Carboniferous are correctly described as such, it follows that the slates and graywackes of the Bremner River district, and consequently of the Valdez group, are younger than that part of the Carboniferous represented in the Hanagita Valley. It would therefore appear that they are either late Paleozoic or early Mesozoic.

Grant, after studying the Orca and Valdez groups in Prince William Sound and the Sunrise group on Kenai Peninsula, concludes that "present knowledge indicates the probability that the Valdez group should be referred to the Paleozoic, but its exact horizon is unknown." 1 Recent work by Martin and by Johnson on Kenai Peninsula lends some support to Grant's view that the Valdez group (or the Sunrise group, as it was named on Kenai Peninsula) is of the Paleozoic age, but was no more successful in restricting its age to a particular part of the Paleozoic. Evidence from the Hanagita Valley and Bremner River district indicates (see p. 24) a late Paleozoic or early Mesozoic age for the group and appears to make the Mesozoic age equally if not more probable than the Paleozoic.

The relative ages of the slate and graywacke succession and of the Middle Jurassic sedimentary beds next to be described are unknown, but will be considered later.

MIDDLE JURASSIC ROCKS.

Character and distribution.-A narrow belt of schist, forming a bench with irregular surface 100 to 300 feet above the river, extends along the east side of the Copper from Chitina River to Canyon Creek. This bench is limited on the east by a line of cliffs that forms the front of a second, much higher, bench. The cliffs are composed of massive conglomerate containing well-rounded pebbles and cobbles of argillite, diorite, greenstone, and quartz in a tuffaceous matrix. The conglomerate is associated with tuffaceous beds deposited in water and containing fossils. Both the conglomerate and the tuffaceous beds are cut by intrusive masses of greenstone and by light-gray diorite and are extensively faulted. Furthermore the conglomerate is highly fractured, as if it had been crushed, and it contains numberless veinlets of white chalky alteration products. Not less than 500 or 600 feet of the conglomerate is exposed in this locality, but its thickness is not known with accuracy. 
Evidence indicating a fault contact between the conglomerate and the schist was obtained at several places, though no good exposure of the contact was seen. There is strong evidence in other localities for an unconformity of deposition between the conglomerate and schist, but in this place the contact appears to be marked by a fault.

The fossiliferous tuffaceous beds here grouped with the conglomerate are exposed on the south side of Chitina River near its mouth and form prominent cliffs along the river. They lie immediately east of the conglomerate and are thought to overlie it. The beds are composed of a dark fine-grained sandstone-like rock, slightly calcareous, and showing numerous small flakes of mica on the cleavage surface. The rock is much jointed, slightly altered, and breaks down readily under the influence of the weather, forming talus slopes of angular platy fragments. A considerable amount of this rock is exposed along Chitina River, but it was not recognized farther south along Copper River, although its presence there was expected. Several small areas of unaltered brownish-gray sandstone found east of Taral, however, may represent a phase of the tuffaceous beds, now largely removed by erosion. On the ridge south of Taral Creek this sandstone contains much quartz, numerous grains of clear unaltered feldspar, and flakes of biotite in a calcareous cement, and also some small black spots, which are thought to be organic remains, but which are too imperfect for identification.

Age and correlation.-Fossils were collected from the tuffaceous beds along Chitina River. They were not found in the conglomerate, however, and, as just stated, the supposedly organic remains seen in the sandstone south of Taral Creek were too poor to be of value. All the fossils were obtained from one locality-at the edge of the Chitina River flood plain, a short distance east of the little creek that drains Taral Lake. They were referred to T. W. Stanton for identification and were described by him as follows:

No. 7231. Ostrea sp., Inoceramus sp. shell fragments, Leda? sp., Stephanoceras? sp., Perisphinctes? sp. The general character of this little collection seems to justify its reference to the Jurassic and to about the horizon of the lower half of the "Enochkin formation."

No. 7232. Inoceramus ambiguus Eichwald. Probably from same formation as 7231.

No. 7233. Inoceramus ambiguus Eichwald?, Stephanoceras? sp. (small fragment). Probably from same formation as 7231. The lower half of the "Enochkin formation" referred to under specimen 7231 is the Middle Jurassic Tuxedni sandstone exposed on the west side of Cook Inlet and described by Martin and Katz. ${ }^{1}$

Jurassic shale or slate, which is widely distributed in the Chitina Valley, attains a thickness of over 7,500 feet in the vicinity of Nizina River, where it rests unconformably on the Nikolai greenstone, the

1 Martin, G. C., and Katz, F. J., A geologic reconnaissance of the Tliamna region, Alaska: U. S. Geol. Survey Bull. 485, pp. 59-64, 1912. 
Chitistone limestone, and McCarthy shale, the last two of which are of Upper Triassic age. The shale in that region, however, occupies a higher position in the Jurassic column than the beds here under consideration. In the western end of the Chitina Valley the Triassic and Jurassic slates north of the river have not yet been differentiated, and it is not known whether they include Middle Jurassic beds of the same age as those south of the river. It is therefore uncertain whether any such Jurassic beds are to be found nearer than the upper part of Matanuska River, where Paige and Knopf discovered sandstone and shale, which Stanton correlated with the lower part of the "Enochkin formation." 1 Lava flows are associated with the sediments in Matanuska Valley, giving evidence that volcanic forces were active there as well as on the Chitina. The Chitina locality is a new one for Middle Jurassic rocks in this part of Alaska. It seems probable that the area of such rocks is more extensive than is now known, and there is reason for thinking that some of the little-known sediments on Kotsina River may eventually prove to be of this age.

\section{QUATERNARY DEPOSITS.}

By Theodore Chapin.

\section{GENERAL FEATURES.}

Unconsolidated deposits floor all the depressions of this area. They consist of bowlders, gravel, silt, and clay arranged in all degrees of stratification, from that of typical moraine to that of assorted sedimentary material evidently of lacustrine origin. Dunes of windblown material occur along Copper River. Igneous rocks also occur in the gravels in relations that show them to be of Quaternary age.

On the retreat of the ice all the larger depressions were floored with gravels of glaciofluvial origin, which were spread out as aprons and valley trains beyond the retreating ice front. Their deposition has evidently been uninterrupted since the retreat of the glaciers and is still in progress. Deposition by glaciofluvial action, however, is at present slight, for, although many glaciers are still actively discharging débris, the material accumulated by this process is confined to the upper part of the valleys and is insignificant in comparison with that removed by erosion by the same streams lower down. Erosion in the lower parts of the valleys has been contemporaneous with glaciofluvial deposition farther up almost since the beginning of the retreat of the ice, for while the glaciers were discharging and depositing material above, erosion was operative below, the new channel pushing its way up through the glacial gravels.

This process of stream adjustment has resulted in a physiographic feature common in this region. In their upper parts the streams

1 Paige, Sidney, and Knopf, Adolph, Geologic reconnaissance in the Matanuska and Talkeetna basins, Alaska: U. S. Geol. Survey Bull. 327, p. 19, 1907. 
flow in meandering courses over broad, flat-bottomed, gravel-floored valleys, and in their lower parts they flow swiftly through entrenched channels, many of them cut deep in the flats built by the redeposition of the gravels by the streams. Streams heading in glaciers are overloaded with débris and in their upper parts they actively deposit, anastomosing and aggrading their channels. Streams not heading in glaciers, although differing in many respects from glacial streams, also deposit débris near their sources, for small steep, actively eroding headward tributaries have their velocities suddenly checked upon reaching flat-bottomed deglaciated valleys and there drop their loads of débris, building up their floors in a manner comparable to that of glacial streams. Streams of both these types, however, soon drop their overload and become graded. The lower limit of this deposition fluctuates and on glacial streams is influenced by the rate of melting, which is a function of the season of the year and even of the time of day. In the graded parts of streams neither corrosion nor transportation is very active and little of either erosion or building is effected, the main work seeming to be the reworking of the glacial gravels in the ever-shifting channels. This balance between erosion and deposition, however, must be regarded as ephemeral, for the graded portion of the stream may be encroached upon by deposition from above or may be destroyed by erosion from below.

Below thair graded parts the work of the streams is mainly degradational. Great quantities of material are displaced by erosion, for the streams are either cutting into the glacial deposits or have completely removed them. Erosion, however, is not the only process effective here, for many streams deposit gravel in ponded stretches or in lakes along their lower portions. In a general way, however, the upper parts of the larger tributary streams are building up their channels, the lower parts are eroding them, and the intermediate parts are flowing over graded flats.

These surficial deposits may be divided into two groups, glacial deposits and stream and lake deposits, but these grade into each other, so that a definite line of demarkation between them can not invariably be drawn.

\section{GLACIAL DEPOSITS.}

Gravels.-Gravels of glaciofluvial origin are best developed along Copper River from Taral northward and along the lower part of the Chitina. Near the mouth of the Chitina they attain a thickness of $600^{1}$ feet and represent only that part of the original deposit that has not been removed by erosion. The cliff along Copper River between the Chitina and the Kotsina exposes a section including 100 or more feet (see Pl. III, $A$ ), built up of layers of gravel, sand, and clay from

\footnotetext{
${ }^{1}$ Mendenhall, W. C., Geology of the central Copper River region, Alaska: U. S. Geol. Survey Prof. Paper 41, p. 62, 1905.
} 

3 inches up to several feet in thickness. The bowlders of the gravel, which include such material as granite, diorite, slate, graywacke, porphyry, and various basic rocks, are in part rounded and in part faceted and subangular, as they commonly are in deposits of glacial origin.

Embedded in this gravel terrane is a mass of volcanic ejectamenta apparently contemporaneous with the deposition of the gravel.

The area under discussion borders the Copper Basin, as described and defined by Schrader and Spencer. ${ }^{1}$ This basin is floored by a sheet of gravel extending far to the northwest and attaining a maximum thickness of possibly 1,000 feet, of which the gravels of the Hanagita and Bremner valleys and their tributaries may be regarded as apophyses. On the Hanagita near the mouth of Sangaina Creek erosion by the present stream has exposed stratified beds of gravel 200 feet thick. The bowlders here are granite, diorite, slate, and gneiss. No clay beds were seen. Bedrock at this point was not uncovered, so the entire thickness of the deposit is not known, Extensive deposits of this same terrane lie at the mouth of Sangaina Creek. Similar gravels are abundant on the Tebay above the Hanagita Valley but have been in large part reworked by the streams. Remnants of this old terrane still cling to the sides of the valley high above the present stream bed. The floor of the Hanagita Valley is moss covered, but dissection in a few places exposes a gravel sheet which evidently covers the entire valley.

On the upper part of Bremner River and its larger tributaries glacial gravels attain a thickness of several hundred feet. Above Twelvemile Canyon the floor of the valley is not much dissected and the total thickness is not exposed. Below the canyon the glacial deposits have been largely reworked, but high benches of them remain along the borders of the valley. Extensive beds of these gravels are found along the lower part of the Little Bremner River as far up as East Fork, above which they have been largely reworked. Glacial gravels occur in ill-defined terraces on Golconda Creek in the vicinity of Shovel and Standard creeks.

On Taral and Canyon creeks wedge-shaped masses of stratified gravel which in cross section show much greater thickness than width cling to the steep-walled sides considerably above the floor of the canyon. They owe their formation to deposition by streams that flowed along the borders of the glaciers. Well-stratified deposits somewhat similar in appearance but of different origin lie at the mouths of tributaries of the valleys once occupied by large glaciers and extend some distance upstream, thinning out in that direction. They appear to have been laid down in standing water due to ponding

1 Schrader, F. C., and Spencer, A. C., Geology and mineral resources of a portion of the Copper River district, Alaska: U. S. Geol. Survey special publication, p. 29, $190 \mathrm{I}$. 
of the tributary streams by ice in the main valley. Each of the streams so ponded has since dissected the deposit it formed, leaving a roughly triangular area of gravel on each side.

Moraines.-Moraines are of small extent in comparison with the other glacial deposits and with few exceptions were noted only in the vicinity of the Tebay and its tributaries. Their former existence in greater abundance is inferred, however, for their preservation could hardly be expected in a region of vigorous glaciofluvial activity. A terminal moraine that stretches across the valley at the head of Hanagita Creek has proved an effective drainage barrier, ponding part of the natural drainage of Klu River, forming several small lakes, and diverting the drainage into Hanagita Creek. 'This moraine (see Pl. V, p. 40) is a crescent-shaped ridge of unusual symmetry of form, convex toward the Hanagita Valley. It is 15 to 20 feet high and several hundred feet wide and incloses a number of kettle-like depressions. Southeast of the mouth of Sangaina Creek the remnant of a lateral or terminal moraine forms an irregular ridge over a mile in length, broken by knobs and intervening hollows. In the lower part of the Hanagita Valley and in the vicinity of the Tebay numerous irregular hummocks and ridges, called kames, inclose undrained basins and kettle-like depressions, the whole forming irregular morainal deposits of the knob and kettle type. The low divides that stand below the limit of glaciation, where glaciofluvial action was less intense and the low relief of the surface tended to preserve loose deposits from stream attack, are generally covered with a veneer of morainal débris, and erratic bowlders on the mountain sides are evidently remnants of morainal accumulations.

The smaller glaciers of the region are entrenched in cirquelike basins having high perpendicular walls. At the front of each cirque is a mass of morainal material dropped by the melting ice and unmodified by the erosion of the issuing streams, which are not strong enough to distribute the débris. The material of these deposits was derived entirely from the cirques and is therefore essentially homogeneous. The bowlders have not been transported far and are therefore angular and the deposits lack fine material such as clay and gravel. Thus in these particulars the recent moraines differ from the heterogeneous subangular material of the typical moraine.

\section{STREAM AND LAKE GRAVELS.}

Alluvium, derived from glacial deposits and from disintegrating rocks, is now being spread over the flood plains of the streams throughout the district. It might be subdivided into deposits of reworked glacial material and later deposits not connected in any way with glaciation, but formed essentially of near-by country rock, yet the two types grade into each other so intimately that they can not 
everywhere be separated. Alluviation is best exemplified along the larger streams, such as Copper and Chitina rivers, where broad flood plains are developed, but is also active on nearly all streams and in places has formed thick beds. In the vicinity of Tebay. Pass two series of well-developed stream terraces are developed. One of these, on Bridge Creek, a mile above the Tebay, consists of nine-distinct terraces, seemingly old flood plains of Bridge Creek; the other borders Falls Creek, on the south side of Tebay Pass. Along Bremner and Little Bremner rivers former flood plains are represented by low, flat benches. The present flood plains are broad, flat alluvial stretches and are not easily distinguishable from deposits of lacustrine origin, to which they are similar and into which they merge.

Along the Little Bremner lies a series of broad alluvium-covered flats separated by stretches of swift water flowing through steepwalled narrow gorges. The upper one of these flats has been prospected by drilling and found to consist of an upper stratum of alluvium and an underlying much greater thickness of clay and sand, probably in large part of lacustrine origin, the whole having a thickness of about 50 feet. The similarity of this flat to the others suggests that all of them were once covered by lakes. This has not been demonstrated, however, for the alluvial covering masks all earlier deposits. The gravels of the broad flats of the Bremner just above Threemile Canyon also appear to be of lacustrine origin; the placer workings here reveal 12 feet of fine gravel sorted and stratified to a degree that indicates wave action. The extent of this lake bed is not known, for the surface is covered with alluvium. This alternation of alluvial flats and narrow gorges is a glacial feature that is well developed in this region, especially in the valley of the Little Bremner. It may result from the filling of glacial lakes caused by the uneven glacial erosion of the valley floor.

A large alluvial fan at the mouth of the creek tributary to Hana gita Lake from the south has been in part at least the cause of the formation of the lake. The creek when rapidly eroding the thick deposits of glacial gravels that once stood across it, remnants of which still remain on its sides, was not able to carry off the abundance of loose material and was forced to deposit it in a fan that has crowded Hanagita Creek far toward the side of the valley and dammed back its waters, thus forming the lake. The stream has now shifted to the east side of the fan and enters the lake in a direction exactly opposite to the course of Hanagita Creek.

\section{EOLIAN DEPOSITS.}

Wind-blown sand dunes are common along the larger streams of the Copper River basin, and some thick dunes lie near the mouth of Chitina River. The ever-shifting channels of Copper River 
expose to the action of winds an enormous amount of fine material, which the prevailing north winds of summer gather up and carry off in great quantities. Waves of fine sand and dust resembling lowhanging banks of fog roll up the canyon, and the finer particles are transported for miles, large quantities being deposited along the banks of the river among the vegetation. A place peculiarly adapted to its deposition seems to be the north bank of Chitina River, near its mouth at the abrupt turn of the Copper, where the velocity of the silt-laden winds, already lessened by the widening of the canyon, is further checked and much of the material is collected. The shifting dunes have encroached on the vegetation and have nearly covered some of the smaller trees. A large proportion of the soil of the region probably consists of wind-blown silts.

\section{IGNEOUS ROCKS.}

\section{INTRUSIVES IN CARBONIFEROUS (?) ROCKS.}

Intrusives are numerous and widely distributed in the Carboniferous (?) rocks. They include several types of igneous rock and occur as dikes and sills and as much larger irregularly shaped masses. They are especially abundant in the vicinity of Taral and on Tebay River.

Granodiorite and quartz diorite are the most common intrusives. Diabase is present in a few localities and one dike of peridotite was found. The diorites belong to several periods of intrusion and show widely different degrees of metamorphism. They also show variation in color, in coarseness of grain, and to some extent in mineralogic composition. They consist essentially of hornblende and plagioclase feldspar ranging from oligoclase to labradorite. Orthoclase occurs in all the specimens, and its presence in larger or in smaller amount forms the principal distinction between the granodiorite and the quartz diorite. A little pyroxene occurs in nearly all the thin sections examined and a small amount of quartz and biotite was found in most of them. Magnetite, titanite, apatite, and zircon are accessory minerals.

The small area between Canyon Creek and Chitina River is in large part a complex of intrusives in which large masses of sedimentary rock have been inclosed. (See Pl. IV, B.) Diabase is the prevailing type, but diorite is common and presents a varied appearance. Much of it has been altered to greenstone, especially in the vicinity of Taral, and was not at first distinguished from the greenstone derived from diabase. Specimens of a dark, fine-grained rock common in this vicinity, which were identified in the field as dolerite, appear on study with the microscope to be, in part at least, a much-altered diabase, although some of it may perhaps belong to the dioritic group or to some more basic type of igneous rock. The eastern half of the mountain northwest of Nerelna Creek is made up of light-gray diorite, much younger, however, than most of the other dioritic 


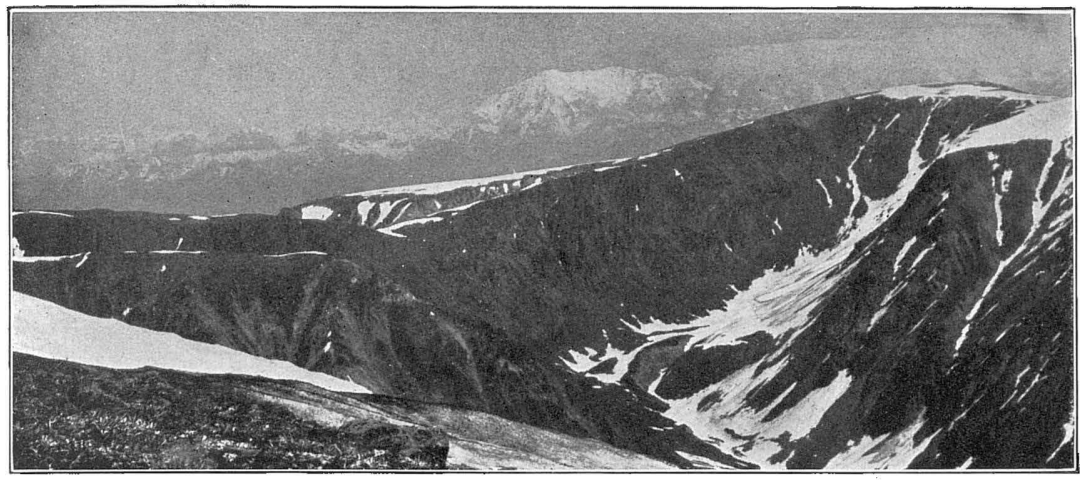

4. TOP OF RIDGE BETWEEN HANAGITA VALLEY AND CHITINA RIVER.

Elevation nearly 6,000 feet. These mountains were overridden by the great glacier of Chitina Valley. Mount Blackburn, 35 miles to the northeast, in the background.

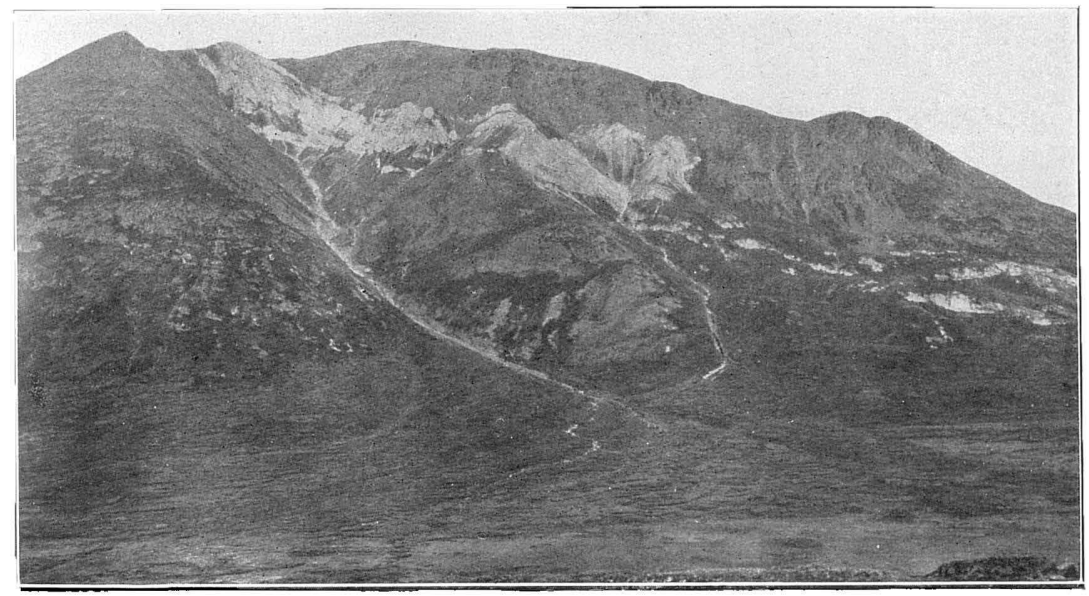

B. LIMESTONE INCLUDED IN GREENSTONE MASS NORTH OF CANYON CREEK AND WEST OF THE TRAIL LEADING FROM CANYON CREEK TO TARAL.

The included mass is about a mile long.

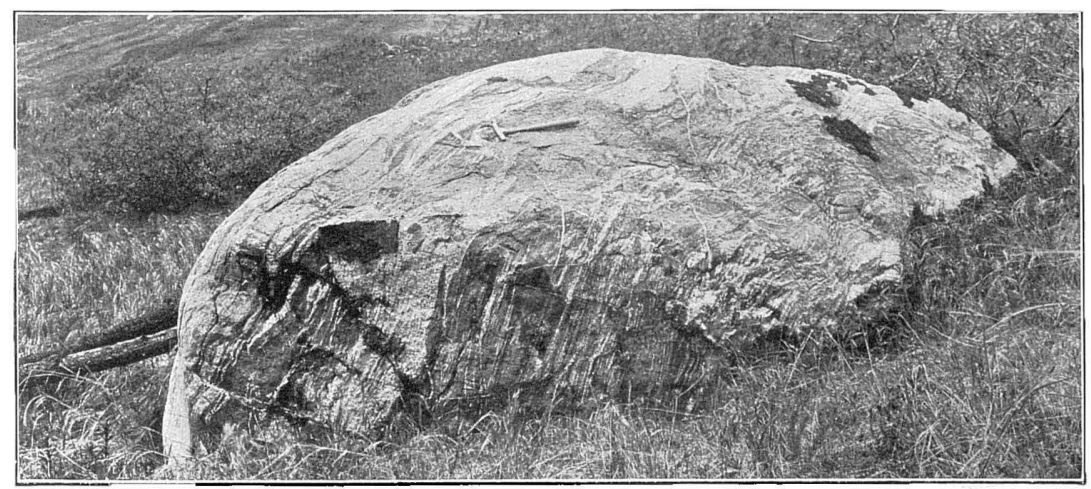

C. BOWLDER OF GNEISS ON TEBAY RIVER.

The altered sediments are here intimately intruded by dioritic rocks. 

intrusives of this vicinity. This rock is little altered but is much fractured, owing to disturbing movements to which the mass has been subjected, and as a result streams have been able to score its sides with deep gulches that are highly conspicuous at a distance because of their white color.

Diabase intrusives are also present here. All of them are considerably metamorphosed, and they are thought to belong among the older, yet not the oldest, intrusives of the district. They appear also to be the rocks with which most of the copper of the district is associated, though they are not the only ones in which it is found. The largest intrusions of this kind are in the vicinity of Divide Creek and on the east side of Nerelna Creek.

The dioritic rocks of Tebay River show, better than those of any other locality examined, the occurrence of successive intrusions. The oldest intrusions filled the sedimentary beds with igneous material, which so freely penetrated them along cleavage and bedding planes that it obscured or transformed the original sedimentary character of the beds. This mass of igneous and sedimentary rock was folded and considerably metamorphosed and again cut by other dikes and sills. Most of the later intrusives contain a smaller amount of the dark ferromagnesian constituents than the older ones and are consequently lighter in color. The freshest and most recent, composed essentially of quartz and feldspar, are white to brownish gray, and range in texture from rather fine even-grained rock to pegmatite. Segregations of hornblende containing fine large crystals, the largest 6 inches long and nearly an inch in diameter, were found in some of the pegmatitic varieties but are not common. These latest intrusives are very fresh in appearance and except for jointing and faulting show little effect of movement.

The floor of Tebay River valley from the lower lake to a point nearly halfway between the mouth of Hanagita River and Chitina River is formed of a succession of rounded knobs with intervening depressions (see Pl. III, $B$, p. 28), composed of diorite and of sedimentary beds intruded by diorite, whose tops have been swept bare of loose material and smoothed by glacial ice. Rocks like these formed by the impregnation of sediments with igneous material are best described under the term gneiss, for they retain little of their original sedimentary character. (See Pl. IV, C.) The belts east and west of the center of the valley contain less diorite than the area along its center, yet much diorite was seen in the mountains north of Summit Lake. Intrusives are less numerous north of the Hanagita Valley in the east end of the area mapped as Carboniferous.

A dike of peridotite consisting of pyroxene and much-altered olivine with metallic sulphides was found near the head of Canyon Creek. The surrounding rocks are schist and limestone, very much $28566^{\circ}-$ Bull. $576-14-3$ 
folded and extensively faulted. A small peridotite dike appears to have been intruded into the schist and later faulted into the limestone, but it may have cut both rocks originally. Most of the dike is covered with talus material, and the disturbance in the inclosing rock has been so great that the exact structural relations are obscure.

INTRUSIVES IN SLATES AND GRAYWACKES OF THE VALDEZ GROUP.

Dikes and sills of quartz diorite and quartz monzonite cut the slates and graywackes of the Bremner River district, but appear to be more numerous near the boundary between these and the Carboniferous (?) rocks. The mountains between Bremner and Tana rivers were not visited, but the great quantity of diorite in the Bremner River bars shows that the headwaters of that stream must lie in an area occupied by large masses of this rock. Granite (diorite) is reported by prospectors who have been on the upper parts of the two forks of Bremner River.

The diorite is little altered and shows no unusual petrographic features. The rock called quartz monzonite is a light-colored porphyritic intrusive occurring in dikes and sills, which are not particularly conspicuous in the field, but which in a few places attract attention by their persistence with little change in thickness for long distances. The bare cirque walls of Gold Creek at the eastern end of the Hanagita Valley show this feature, and it is seen in other places also. These intrusives are present at the head of Little Bremner River in considerable amount, and they outcrop along the shores of Copper River. The intrusive rocks of this district probably played an important part in the formation of the auriferous veins.

\section{INTRUSIVES IN MIDDLE JURASSIC ROCKS.}

The conglomerate in the vicinity of Taral on the east side of Copper River has been invaded by masses of diabase and diorite,

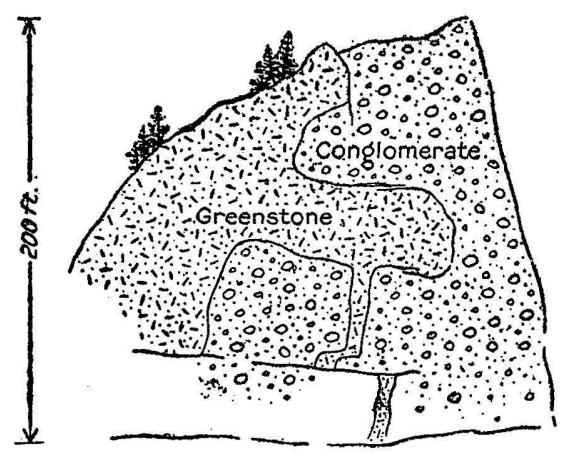

FIGURE 4.- Sketch of greenstone intrusive in conglom erate on the east side of Copper River near Taral. both considerably altered. The diabase and locally the diorite have become greenstones, yet the diorite, which appears to have retained more of its original character, is probably younger than the diabase, although no direct evidence of this assumption, such as would be furnished. by intersecting dikes of the two rocks, was obtained. The greenstone and conglomerate show intricate structural relations that

have been still further complicated by faulting. (See fig. 4.). In places the greenstone is brecciated and filled with soft white vein 
material. It probably is the source of the copper staining observed at a few places.

\author{
AGE OF THE INTRUSIVES.
}

The various intrusive rocks in this region are greatly different in age. The oldest of them have been subjected to the movements that produced schistosity in the oldest sedimentary beds. The most recent are probably much younger than the latest of the sediments.

It has been shown that there is reason to consider a part of the diorite as older than the slates and graywackes. The evidence for this conclusion lies chiefly in the comparative degree of alteration of the diorite and the sedimentary beds and the fact that the oldest intrusive rocks do not extend into the slates and graywackes; although they cut rocks adjacent to them. A late Paleozoic or early Mesozoic age is therefore indicated for the oldest of the diorite intrusives.

Younger and less altered diorite dikes cut all the sedimentary formations of the district. They can not be older than Middle Jurassic, for they cut rocks of that age, and it is suggested by conditions in neighboring districts that they may be younger than Upper Jurassic. The Kennicott formation, on the north side of Chitina River, contains a large amount of intruded quartz diorite similar to that of the Hanagita-Bremner region. This formation is made up chiefly of slate and is shown by the fossils it contains to be of Upper Jurassic age and possibly to extend into the Cretaceous. It is quite possible, if not probable, that the youngest diorite intrusives in the districts adjacent to the western half of Chitina River may be contemporaneous, so that the period of diorite intrusion may have extended over the greater part of the Mesozoic era.

The age of the diabase intrusives is more in doubt. The amount of alteration they have undergone indicates that they belong among the older intrusives, yet it is evident that if the conglomerate at Taral is correctly referred to the Middle Jurassic at least a part of the diabase must be of later age. Age determinations based on differences in the degrees of alteration of different kinds of rock may easily lead to error, yet the difference between the alteration of the diabase and that of the latest diorite intrusives is so great that it was considered in the field to indicate a great difference in their ages.

\title{
STRUCTURE.
}

The important known structural features of the district have been considered in connection with the several groups of sedimentary rocks, but it remains to bring the facts together and show their relations to one another. No attempt was made in the course of the summer's work to study the structure in detail, for much of the areal investigation was carried on without a base map and locations had to be 
made by foot traverse, but it was nevertheless possible to get a fairly good idea of the most common structural types.

The Carboniferous (?) schist and limestone beds are characterized by much folding and faulting. The limestone beds are of particular service in the study of these two structural features, for they show them more plainly than do the slate beds or the intercalated igneous rocks. Throughout the Hanagita Valley and between that valley and Chitina River the strata dip prevailingly north and strike east and west. The northerly dips are presumably the expression of closely compressed overturned folds, but complete proof of this presumption was not obtained.

The cleavage also strikes east and west and in most places dips toward the north. This strike and dip prevails in the cleavage of the schist exposed in the railroad cuts on the west side of Copper River, but not in that on the east side of the river, near the massive conglomerate, for there the strike of the cleavage is north and south, parallel to that of the conglomerate and of the fault which is believed to separate the two formations. Faulting is common in these rocks and is best expressed in the displaced limestone beds.

The massive conglomerate at Taral extends along the river at right angles to the prevailing strike of the older sedimentary beds and is the only conspicuous example of this transverse structure seen in the district. The relations of the conglomerate to the sedimentary beds east of Taral are obscured by the igneous rocks that make up most of the mountains on that side, and the fault between it and the schist on the west and the probable unconformity between it and the underlying rocks are its only contact relations that are known with reasonable certainty. What becomes of the conglomerate and of the schist and limestones north of Chitina River and what relation these rocks bear to those on the north side of Chitina Valley are not known, for that district was not examined. As the floor of Chitina Valley is covered with gravel and as rock exposures in the valley are not good except along streams that have cut through the gravel into the country rock, these problems may be difficult to solve.

The slates and graywackes of Bremner and Little Bremner rivers are much less folded than the schist and limestone beds adjacent to them on the north. In several localities in the vicinity of the contact low dips were noted, which became southerly and increased in amount toward the south as far as the main Bremner. The strike is east and west. The structure, however, is not so simple as would appear from this statement, for evidence of greater folding is found in places. Cleavage that crosses the bedding at high angles is seen here and there, but in general the strike and dip of bedding and cleavage are the the same. 
The nature of the contact between the slate-graywacke group and the schist-limestone group is known only in part. In some places the rocks of these two groups are separated by a fault plane; in others they appear to be separated by a depositional unconformity. (See p. 24.) Faulting is seen along the railroad track at places where only the Carboniferous (?) rocks are involved, but is indicated in the vicinity of the contact by a repetition of beds of slate, graywacke, and schist. Farther east, on Tebay River and in the Hanagita Valley, faulting was not recognized at the contact, although it may exist.

To faulting is probably due in part the arrangement of the stream courses in this district. The principal fault planes are approximately parallel to the main structural lines of the rock formations, or cut across them at right angles; that is, they strike either west-northwest or north-northeast, corresponding to the dominant courses of the streams. (See Pl. I, in pocket.) Schrader ${ }^{1}$ first noticed that the streams coming into the lower part of Copper River from the east and west are arranged in pairs in such a way that the valley of one is practically continuous with that of the other. He ascribed this arrangement to weakness or softness of the rock along these valleys. But variation in original hardness of the different rock formations of this part of the Chugach Range probably does not fully account for this pairing of the east-west streams and can hardly be the cause for the north-south courses of the others. Variation in hardness of the rocks combined with weakness due to faulting, however, may have determined the east-west courses of the streams and the pairing of the Copper River tributaries; and faulting alone may in large part have fixed the positions of the cross streams and the offsets.

\section{GEOLOGIC HISTORY.}

The geologic history of the part of the Chugach Range that lies in the Hanagita-Bremner region may be conveniently divided into two periods, one including the earlier events which have to do with sedimentation, intrusion, and deformation, the other being concerned with processes that are expressed chiefly in the form of the present land surface. Among these processes glaciation holds an important place.

\section{EARLY GEOLOGIC HISTORY.}

The earliest geologic event recorded in the district was the deposition of a series of argillaceous and calcareous sediments that have been referred to the Carboniferous (?) period. Sediments of Carboniferous age are widely distributed in Alaska, so that the sea in which the rocks of the Hanagita Valley were deposited was probably exten-

1 Schrader, F. C., A reconnaissance of a part of Prince William Sound and the Copper River district, Alaska, 1898: U. S. Geol. Survey Twentieth Ann. Rept., pt. 7, p. 398, 1900. 
sive. The conditions attending the deposition were fairly stable; the argillaceous material brought to the sea differed slightly in character from time to time and now and then gave place to calcareous sediments, but on the whole argillaceous material predominated, and there was little variation in its coarseness.

After their consolidation these beds were folded and intruded by diorite. Probably they were also raised above the sea and were subjected to erosion before the next younger rocks were laid down upon them. Their submergence was followed by the deposition of a great thickness of material, mostly argillaceous in composition and of varying degrees of coarseness, that forms the slates and graywackes of the Bremner River valley. This material was probably derived from a near-by land mass and represents a period of relatively rapid erosion and accumulation. If these sediments ever extended over the older formations to the north, the fact has been obscured by their removal during the long time in which the region has been raised above the sea.

No proof is at hand for the relative ages of the slate-graywacke group and the Middle Jurassic beds near Taral, but the indications are that the slates and graywackes are the older. If this is true, a period of erosion involving all the sedimentary rocks of the Hanagita and Bremner River valleys older than Middle Jurassic is probable, for the Middle Jurassic rocks are believed from evidence furnished by other localities to rest unconformably upon the underlying formations. Either before or during this period of erosion the slates and graywackes and the older rocks were folded and subjected to a certain amount of alteration. The disturbance, which continued after Middle Jurassic time and which involved all the rocks of the region, was accompanied by igneous intrusions, by the formation of secondary structures such as cleavage, and by faulting. The land mass was raised above the sea and the processes of erosion were renewed.

These events, related in bare outline, bring the geologic record up to its second period.

\section{IATER GEOLOGIC HISTORY.}

EARLY TOPOGRAPHIC DEVELOPMENT.

The later geologic history of the district includes chiefly events that occurred while the present topography was in process of development-events relating to the formation of the present mountain ranges, the establishment of the drainage system, and the recent modification of the former topography by glacial erosion and deposition.

During early Tertiary time Alaska was subjected to long-continued denudation and lost in large part whatever ruggedness of topography it may previously have had. Its mountains were worn down and its 
depressions filled up. so that the relief was much less than it is now, the land surface showing a succession of low rounded hills separated by broad valleys and level stretches of lowland. On some parts of this land surface there was deposited in Eocene time a considerable thickness of sediments, partly of fresh water and partly of marine origin. These sediments are in nearly all localities coal bearing but show considerable variation in the kind of material composing them. They are not known, however, in the Bremner and Hanagita Valley district.

The deposition of Eocene sediments was followed by mountainbuilding movements which, together with various accompanying geologic processes, gave rise to the Chugach and other ranges, including the great Alaska Ránge. Probably these mountain areas had long been outlined and their places may have been occupied by older ranges before them. They mark zones of crustal weakness and were the first places to yield to the repeated pressures that affected the region. Elevation of the land permitted the agents of erosion to renew their work, the streams were rejuvenated, and the major features of the present drainage system were established, so that when the ice appeared the larger features of the land were probably nearly in their present form. There were, nevertheless, important differences. It is believed, as first suggested by Schrader, ${ }^{1}$ that the Chitina and the Copper formerly drained westward through some unknown channel and that the present course of the Copper through the Chugach Range is of comparatively recent establishment. Such a change in the drainage, though not yet demonstrated, perhaps best accounts for the character of the lower Copper River valley. Minor changes in drainage and in topographic form have also been brought about by the long-continued glaciation.

\section{GI.ACIATION.}

Advance of the ice.-Climatic changes dependent on unknown conditions led to the accumulation of snow in the high mountains and the formation of ice fields. The ice from these fields flowed down into the valleys, and as accumulation continued the valley glaciers advanced over the lowlands until they united and finally filled even the intermountain areas. The Wrangell group appears to have been an important center of ice accumulation, more important than the mountains of the Hanagita and Bremner district, and at the time of maximum glaciation the ice from that center completely filled the Chitina Valley and even overrode the divide between the Chitina and Hanagita valleys. The ice at the mouth of Chitina River must have been fully 5,000 feet thick, for it moved over the mountains east of 
Taral and into the valley of Copper River. The evidences of this movement are numerous. Erratic bowlders of types of rock foreign to the district though native to the Wrangell region lie on mountain tops whose bare ledges are smoothed and striated by the ice. West of Copper River and east of Nerelna Creek are seen, at elevations of 4,000 to 5,000 feet, rolling surfaces that might be taken for remnants of an old peneplain but are believed to have been produced by glaciation, whose work has been only partly destroyed by later erosion.

Traces of work done by southward-moving ice were found in other places. A large ice stream moved southward through the valley of Tebay River and joined the glacier of the Little Bremner, the direction of its movement being shown by the form of the ledges over which it flowed. Possibly, however, its direction may have been reversed during later glaciation, when the ice had gone from Chitina Valley, for the present grade of the Tebay Valley is to the north.

All the valleys of the Hanagita and Bremner district were once filled with ice and are strongly glaciated. Many of their present salient topographic features, however, are the products of later stages in glaciation, especially those of the Hanagita Valley, for the ice barrier of the Chitina must have stopped the northward movement and, to some extent, the eastward or westward movement of the ice in this valley and its tributaries. Later, however, free and extensive movement of the ice took place in the eastern part of the Hanagita Valley, as is shown by its straight, over-steepened walls and its hanging tributary valleys. (See Pls. V and VI.) Such evidences of glaciation are much less pronounced on Canyon Creek, a fact that leads to the belief that less ice passed that way. Tributary valleys like those of the Sangaina, of the stream flowing into Hanagita Lake, of Klu River, and of Monahan Creek show the same peculiar glacial forms and still contain small glaciers in their upper parts.

The Bremner River valley shows the effects of glaciation even more than the Hanagita Valley. North Fork flows between mountains that were glaciated practically to their tops, the walls of its valley are straight and oversteepened, and its principal tributaries flow in hanging valleys. The main valley of Bremner River is broader than that of North Fork, so that the ice was less closely confined, but its topography shows the same general features. The upper valleys of all the forks of Bremner River are still occupied by glaciers.

Little Bremner River valley shows less evidence of glaciation than would be expected when it is remembered that it possibly at one time received considerable ice from Tebay River and that the Little Bremner itself and most of its tributaries still flow from small glaciers. Although its eastern wall is oversteepened, its valley lacks the truncated spurs and straightened sides that are seen on other streams of the district and that attest the movement of large masses of ice. 


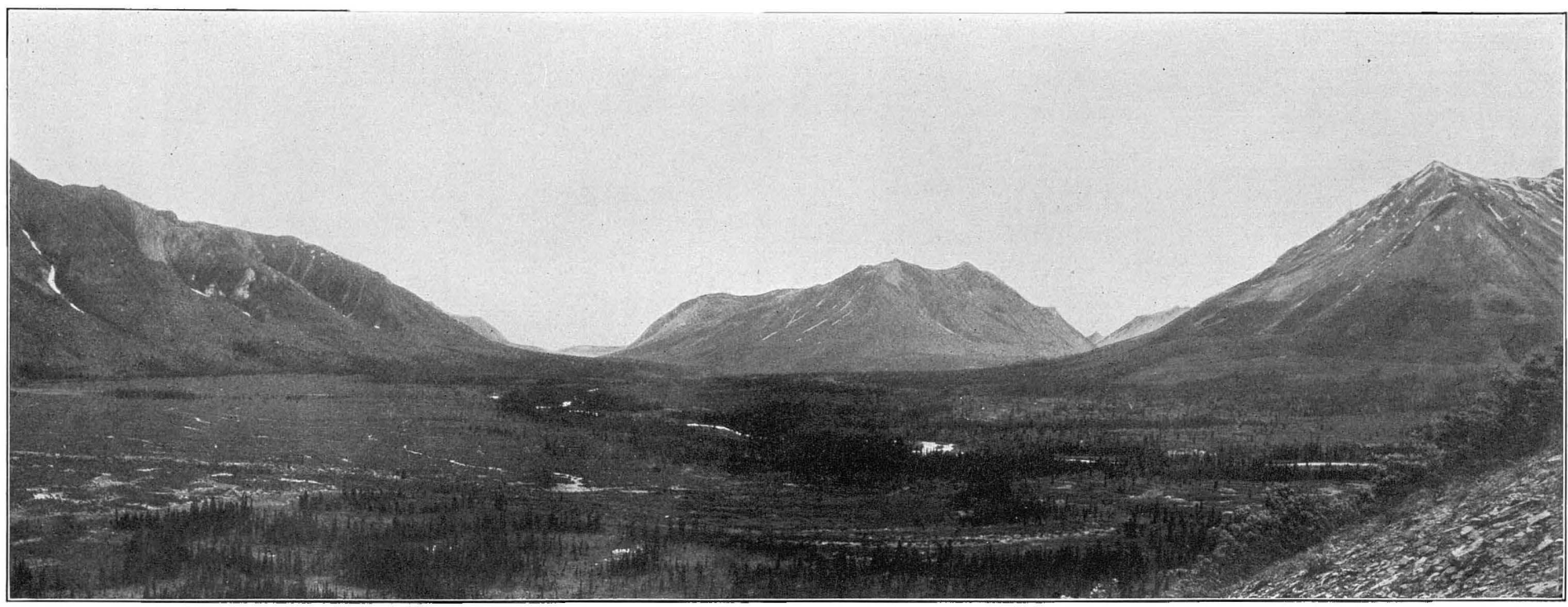

EAST END OF HANAGITA VALLEY.

Klu River flows northeastward on the left side of the mountain in middle of picture. Moraine that crosses the valley is seen on the left side of the picture. 


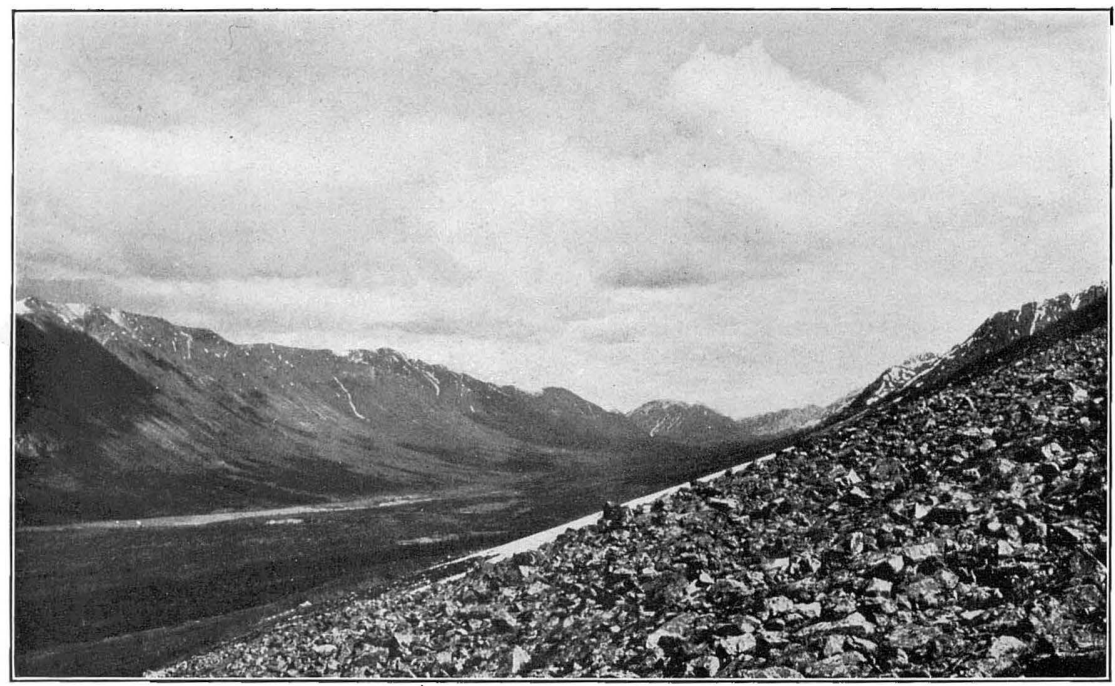

A. VIEW EASTWARD IN HANAGITA VALLEY FROM SANGAINA CREEK.

The glaciation of the valley is evident.

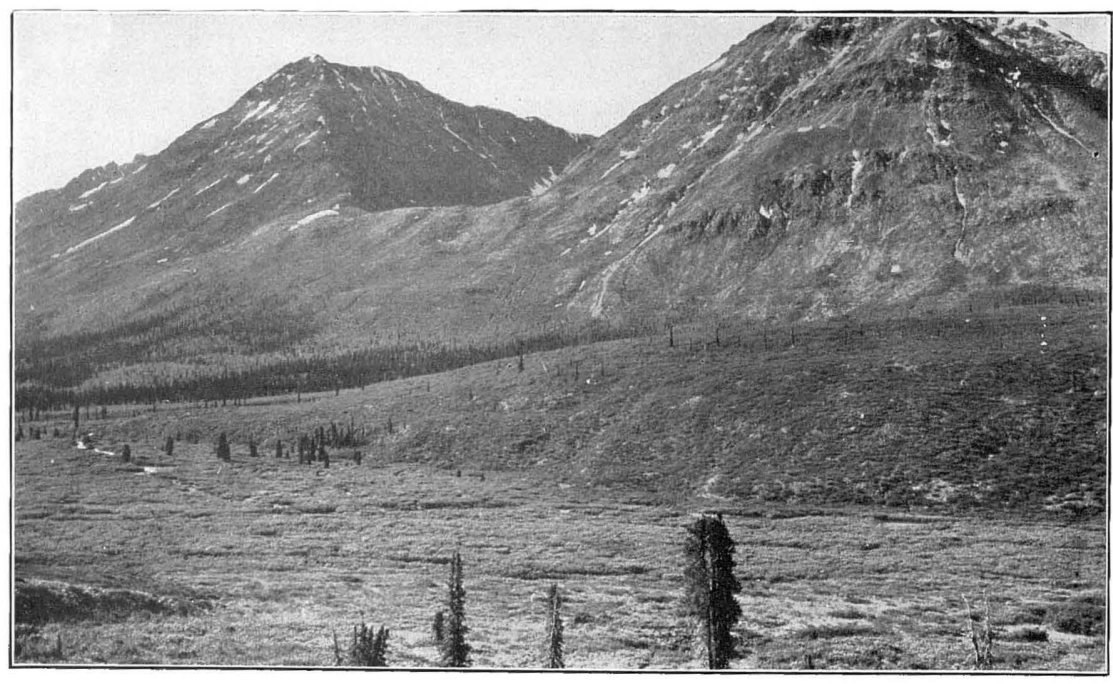

B. HANGING VALLEY ON SOUTH SIDE OF HANAGITA VALLEY NEAR HEAD OF hANAGITA CREEK. 
This might be taken to indicate that the southward movement in the Tebay Valley extended no farther than to the Little Bremner glacier and that it contributed little ice to this valley. Whether this is true or not, the Little Bremner Valley must have contained much ice of local origin. Possibly the force of the glaciers in the western tributaries prevented the glacier moving down the valley from attacking its western side as forcefully as it did its eastern side.

Retreat of the ice.-For a long time the ice has been gradually retreating toward the heads of the valleys and the higher mountain areas. Some of the present glaciers are large, but they are insignificant in comparison with the great mass of ice that once practically covered the district. The retreat of the ice indicates another climatic change, for it is evident either that precipitation is less or that other conditions leading to accumulation of ice are different. The glaciers retreated slowly, and their withdrawal probably caused many modifications of the drainage. Vast quantities of débris were deposited by the glacial water, obstructing or destroying earlier stream channels and establishing new drainage courses. The ice itself was in places a formidable barrier, and doubtless in part determined the present course of Copper River across the Chugach Range.

It has been held that the present course of the lower Copper was established before the Chugach Range was uplifted and that the river has maintained its position by downward erosion as the land was elevated. ${ }^{1}$ This hypothesis has not been disproved, but there is as much to be said in favor of another explanation. The valley of Copper River across the Chugach Range, though narrow throughout, widens considerably in its lower part, especially below Tasnuna and Bremner rivers. In this stretch of the river several large tributaries, the two streams just mentioned and Tiekel River being the largest, drain hundreds of square miles of mountainous country between Chitina River and the coast. In the vicinity of Wood Canyon the river has cut a narrow channel through a broad divide to a depth of nearly 1,000 feet. All the valley is notably glaciated, it being evident that a vast amount of ice moved through it toward the sea. It seems probable that in preglacial time a stream that had been developed where lower Copper River now flows was the principal southwardflowing drainage channel of this part of the Chugach Mountains and that its headwaters were separated from Chitina Valley by a divide at Wood Canyon. The establishment of glacial conditions caused the ice of Chitina Valley to spill over this divide, broadening and lowering it, and during the later stages of glaciation ice gave place to water, which poured over the divide in large volume. These conditions were maintained long enough for the Copper to entrench

1 Spencer, A. C., Pacific mountain system in British Columbia and Alaska: Geol. Soc. America Bull., vol. 14, pp. 126-127, 1903. 
itself across the divide in Wood Canyon and to establish its present channel. Other factors, such possibly as elevation along the western border of the Copper River basin, may have helped to dam the flow of water in that direction, but glaciation was no doubt an important factor in forming this channel.

There is evidence that the ice of the Chitina Valley maintained an elevation about equal to that of the Wood Canyon divide for a considerable period. The military road leading northward from the town of Chitina traverses for several miles a narrow canyon-like valley, at least 600 feet deep, cut on the mountain side and trending

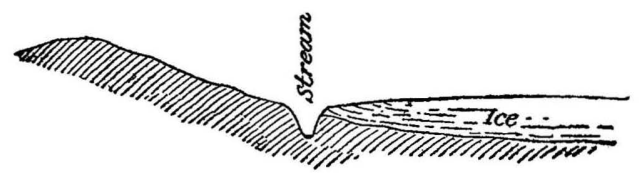

Frgure 5.-Diagram illustrating the formation of a stream channel transverse to a mountain slope at the margin of a glacier. transversely to the mountain slope, or parallel to Copper River. Both ends of the canyon are above the level of the river. This canyon was probably originated by a stream that flowed along the mountain at the edge of the glacier and was deepened and otherwise modified by postglacial erosion. The conditions required for its formation are represented in figure 5 .

Since glacial conditions began to disappear from this region all the streams have been engaged in adjusting their grades so as to accord with the changed topography. It thus happens that the lower end of nearly every stream flows in a canyon cut in the glaciated rock floor of its valley. On some streams, as Little Bremner River, there is a succession of canyons separated by wide gravel-filled basins, all of which owe their presence to glaciation. The condition which made these features possible was erosion by ice of the valley floor, particularly in the headwater part, which destroyed the original stream grade and in

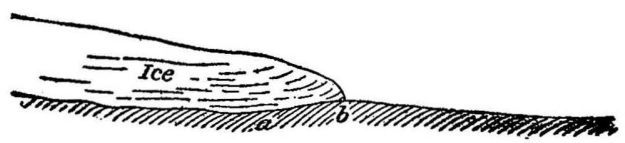

FIGURE 6.-Diagram illustrating one method of formation of a canyon and a gravel-filled basin on a glacial stream. Ice moving down the valley erodes its bed at $a$, below the previously established grade. When the ice retreats the stream fills the basin $a$ with gravel and cuts a canyon at $b$. places even formed basins through whose rock rims the water later cut its channel. Such conditions are represented in figure 6 .

Deposition of their heavy loads of glacial débris by streams during the retreat of the ice was an important factor in giving the present form to many valleys. In places, as on the upper part of Tebay River, the glacial gravel is almost lacking and bare rock is exposed on the valley floor, yet most valleys contain extensive deposits of this kind. The streams are now re-sorting and gradually removing the gravel, but the larger ones are still so loaded with débris derived from existing glaciers that deposition practically keeps pace with removal. 


\section{ECONOMIC GEOLOGY.1}

\section{MINING DEVELOPMEENT.}

It has been known for many years that the Indians of Copper River had knowledge of a source of native copper and that they used the metal in making various objects, such as arrow and spear points, bullets, and knives. In 1885 Maj. (then Lieut.) H. T. Allen, under direction of the War Department, ascended the Chitina and Nizina valleys as far as Dan Creek in an endeavor to learn something concerning the reported occurrence of copper in that district. $\mathrm{He}$ had been preceded in the first part of his journey by John Bremner, a prospector, whom Allen found living in a destitute condition at Taral when he arrived there in the early spring. Bremner had been compelled, on his way up the Copper during the previous summer, to stop at the mouth of the stream which now bears his name, but whatever prospecting he may have done in this district met with little success. Allen's search for information regarding copper in Chitina Valley did not yield much definite knowledge either, yet he was able to confirm its reported occurrence and to learn, as was later confirmed by Hayes, ${ }^{2}$ that the natives obtained it from the head of White River. 3

The first organized search for valuable minerals in the Chitina Valley was made in 1898 and resulted in the finding of copper lodes in a number of places, one of which was on the south side of Chitina River about 8 miles above the mouth. Since then prospecting for copper has been carried on spasmodically, and several other promising lodes have been discovered. One near Taral was patented but has not been developed, because, until recently, there was no means by which the ore could be shipped to the smelters. There has been, therefore, no production of copper in the district nor is any likely for a number of years.

The gold: placers of Little Bremner River and Golconda Creek were discovered in 1901 by two small parties of prospectors from Valdez, one consisting of Peter Monahan, Guy Banty, and Henry Anderson, and the other of Harry Happell, W. H. Hawes, Angus Gillis, and Ralph Wheaton. These men spent part of the summer prospecting on different tributaries of the Bremner and staked Golconda Creek on October 11. Placer mining has been carried on there each year since, during which time most of the different holdings on the stream have been consolidated and are now controlled by two men. In 1911 the Golconda Mining Co. secured an option on eighteen claims and

\footnotetext{
1 Most of the matter here given under "Economic geology" was published under the title "The Taral and Bremner River districts" in U. S. Geol. Survey Bull. 520, pp. 93-104, 1912.

2 Hayes, C. W., An expedition through the Yukon district: Nat. Geog. Mag., vol. 4, p. 143, 1892.

8 Allen, H. T., Report of an expedition to the Copper, Tanana, and Koyukulk rivers in the Territory of Alaska, Washington, p. 158, 1887.
} 
installed a hydraulic plant which was completed in the latter part of the summer, too late for more than a short season's run.

Golconda Creek produced most of the gold mined in the district up to the present (1914). Little Bremner River has only a small production. The main Bremner and Fern Creek, a southern tributary of the Bremner, have yielded not more than a few hundred dollars. Gold has not been found in commercial quantities in the Hanagita Valley nor in the mountains east of Taral. Considerable prospecting was done on Monahan Creek in 1902; most of the stream was staked but the claims were later abandoned.

In early years most of the conditions affecting mining in the district were highly unfavorable and greatly retarded development. Since 1910 a change for the better has come with the completion of the railroad up Copper River. Improved transportation facilities; lower freight rates, and easier communication with the coast have already stimulated prospecting.

The known mineral resources of this district, as has been pointed out, include only gold and copper. The two metals appear to be almost restricted to certain rock formations and to areas that are fairly well defined by the distribution of those formations. A knowledge of the areal geology of the district should therefore be of much aid to prospectors seeking either of these metals.

\section{GOID.}

\section{SOURCE AND DISTRIBUTION.}

The belt of interbedded slates and graywackes that extends westward from the head of Bremner River to Kenai Peninsula is auriferous in many places if not throughout its known length. This belt of sedimentary beds is intruded by light-colored dioritic dikes and is cut by numerous veins of quartz. Most of the quartz veins are short, pinching out within a few feet along the strike, but some of them can be traced for considerable distances and are evidently connected with extensive fissures. By far the greater number are small, ranging in thickness from an inch or less to a rare maximum of several feet. Many such veins contain gold in amounts ranging from a trace to quantities large enough to make the veins commercially valuable as mining property, and in them is believed to be the source of the placer gold of this district. The veins commonly contain a small proportion of metallic sulphides, among which pyrite is predominant and galena and molybdenite are found.

Gold can be panned from practically all the streams of the Hanagita and Bremner.River valleys that traverse areas of slate and graywacke but is found in only a few of them, such as Golconda Creek; Little Bremner River, and parts of the main Bremner, in sufficient amount to encourage mining. Here, as in many other sections of Alaska, 
the most promising gravels are those which represent a reconcentration of the bench deposits. The gold in the bench gravels has already received a first concentration during the processes of erosion and deposition to which it has been subjected, and is reconcentrated where streams have intrenched themselves in the benches, thereby removing or "ground sluicing" away a large amount of gravel and leaving behind the contained gold.

\section{GOLD PLACERS.}

Golconda Creek.-Golconda Creek is tributary to North Fork of Bremner River, joining it 5 miles below the great glacier whose waters are the principal source of the latter stream. It heads in the mountains between the Hanagita Valley and the Bremner and is a clear-water stream, although it derives much of its flow from melting snow in spring and early summer. Its course is southwestward and its length from the little lake at its head to the point where it unites with the Bremner is between 8 and 9 miles, in which distance it falls 2,600 feet, or at an average rate of about 300 feet to the mile.

The Golconda Creek valley shows the characteristics common to the smaller valleys of the region. Its U-shaped cross section and straightened sides are unmistakable evidences of glaciation, and it possesses the customary deep rock-walled canyon in its lower course and wide gravel flood plain near its head.

The head of Golconda Creek is separated by a broad low pass from Monahan Creek, which affords a route of travel either westward into the Hanagita Valley or northward to Chakina River, which in turn empties into Chitina River 4 miles above the mouth of the Nizina, and thus provides what is at present practically the only winter route from the upper Bremner River and its tributaries to the railroad. Freight for Golconda Creek, including a small hydraulic plant, was taken in over this route in 1910. The pass has an elevation of 4,000 feet above the sea. It is about 1,000 feet above timber on the Monahan Creek side and is only 1,200 feet above the principal placer workings of Golconda Creek.

Golconda Creek lies wholly within a slate area (see Pl. II, in pocket), but the slate is cut by numerous light-colored, fine-grained dikes of dioritic porphyry whose presence is distinctly shown in many places on the bare mountain sides. The slate exposed along the creek is hard and siliceous and locally is almost schistose. Its cleavage, which appears to correspond closely in dip and strike with that of the bedding, is nearly horizontal, for the most part dipping slightly to the south, but in places shows a low northerly dip. Perpendicular joints cause the slate to break into angular blocks and slabs and, as disintegration has not advanced far enough since the recent glaciation to soften the rock and make it crumble, great piles of these large slate fragments are seen on the dumps of the placer workings. 
The stream gravels of Golconda Creek are shallow. Only in a few places are they known to have a thickness greater than 8 feet. They consist chiefly of slate but contain a small proportion of diorite. Diorite bowlders, the largest several feet in diameter, are included in the heaps of slate slabs on the mine dumps, but fortunately for the miner they are much less common than the slate. Most of the slate slabs can be broken with a sledge and then carried away, but the diorite is too hard for this treatment and requires powder to break it into pieces small enough to handle.

For the most part the stream gravels are reworked material from the high bench gravels in which the creek has incised its present channel and formed its narrow flood plain. The placer workings thus resemble those of many other Alaskan districts, such as Chititu, Dan, and Valdez creeks, where the rich gold-bearing gravels are a reconcentration of earlier, more widely disseminated deposits that are now being dissected and redeposited by the present streams.

The benches, which are prominent in many places on both sides of the channel, may prove to be a source of gold in the future, although they have not yet been mined nor even prospected. They are known to contain gold in some places and there can be little doubt that they are the source of a part if not almost all of the gold reconcentrated in the creek gravels.

The Golconda Creek gold is described by the miners as "shot gold;" thin flaky pieces are uncommon. Many pieces are worn smooth, but in general the gold is rough and little worn and many pieces of it carry included quartz. A nugget found on the creek in the early days and valued at $\$ 52$ is the largest piece of gold yet taken from the gravels.

Most of the mining on Golconda Creek during the seven or eight years following the discovery of gold in 1901 was carried on a short distance below Standard Creek, or about 4 miles below the head of the stream. Pick and shovel were used at first, but later a small hydraulic plant was employed in connection with a dam and "boomer" for disposing of the tailings. In 1911 the Golconda Mining Co. installed a hydraulic plant on the stream at the head of the canyon about a mile below Standard Creek. Most of the summer of 1911 was devoted to putting this plant in place and getting it into shape for work. The company built a mile of ditch line, which took water from Standard Creek and other small eastern tributaries of Golconda Creek and delivered it at the penstock with a head of approximately 250 feet. From the penstock the water was conducted to the giants by an iron pipe 1,800 feet long. Over 100 feet of 30-inch flume was in place on August 1, 1911, and bedrock had been reached at its upper end. 
If more extensive hydraulic mining operations are carried on here in the future it will be necessary to provide a greater water supply, for that in use in 1911 was barely sufficient for needs at that time. Additional water can be obtained by extending the present ditch line so as to tap the upper part of Golconda Creek and tributaries such as Shovel Creek. The elevation of the gold-bearing gravel is such as to make it difficult to bring water from sources outside this valley. The high elevation also affects mining by increasing the cost of lumber, for the productive part of Golconda Creek is above timber line, making it necessary to bring logs for lumber and general mining purposes from Bremner River or Monahan Creek.

Bremner River.-Bremner River has little importance as a goldproducing stream at present. No mining was in progress on the north fork in 1911 and work on the main river was confined to one locality just above the head of Threemile Canyon.

The valleys of the lower river and its branches bear evidence of intense glaciation (see p. 40), and even now practically all the important tributaries of the Bremner River system head in glaciers, some of which, like those giving rise to the three principal branches, are of large size. North and Middle forks and also the main stream below the forks traverse an area of slate and graywacke, but the quantity of diorite pebbles and bowlders on the river bars shows that important bodies of igneous rock must lie in the mountains between Bremner and Tana rivers, particularly at the head of North Fork of Bremner River.

The retreat of the ice in these valleys gave opportunity for the deposition of large masses of gravel that in places doubtless once extended continuously across the valley floor but that have been cut into and in part removed by the river, the remnants lying along the valley sides in the shape of high benches.

The mining near Threemile Canyon in 1911 was carried on in the lower gravel benches of this kind. A ridge of slate and graywacke had formerly dammed the river, probably producing a lake and causing a great quantity of sand and fine gravel to be deposited. As the river gradually cut its channel into the slate and formed the canyon it also cut the gravel deposits above and developed a succession of benches. Fine gold is present in these benches and may be panned from almost any of the river bars. The amount, however, is so small that it has not offered particular encouragement to prospectors.

In the early part of the 1911 season two men were at work on the north side of the Bremner about half a mile above the canyon. A cut averaging approximately 10 feet in depth had been carried down to bedrock and extended 100 to 200 feet back from the water in the first low bench bordering the river. The bench at this place consists 
of sand and fine gravel, probably laid down in quiet water, resting on a slate or graywacke bedrock with a smooth undulating surface produced by glacial erosion. Water for sluicing was brought from a little stream near by and although the head was small it was possible to move a large mass of material in a very short time owing to the fineness of the sand and gravel. Work was interrupted about the middle of summer by failure of the water, in consequence of which the gold production was disappointingly low.

Too little prospecting has been done to furnish any proper estimate of the gold content of these gravels. The gravel deposits are extensive, and vast amounts of them are so fine that they can be handled easily; doubtless, however, they contain some bowlder beds that would offer difficulties. An excellent water supply with good head can be obtained at little expense from the small streams on the north side of the valley, the topography being such that a number of them can be combined with comparatively little labor.

A branch of Bremner River which joins the main stream near the lower end of Threemile Canyon was the object of some interest in 1907. An option on a number of placer claims was obtained and a party was sent in to exploit the ground. Returns, however, were so unsatisfactory that the project was abandoned in the middle of the summer, and in 1911 only one man was at work on the stream.

Little Bremner River.-Little Bremner River was the first stream in the district to receive attention from placer miners and was once the scene of considerable mining activity. The richer placers of Golconda Creek, however, drew a part of the population to the upper Bremner country, and for several years interest in the Little Bremner was low. It revived somewhat in 1910, but late in the summer of 1911 only three men were at work in the valley.

The Little Bremner is a glacial stream about 12 miles long which derives most of its water from melting snow and ice in the mountains southeast of Spirit Mountain, on Copper River. A broad, low pass connects it with the head of Tebay River and thus with the Hanagita Valley.

The valley of Little Bremner River, though strongly glaciated, does not show such a pronounced U-shaped cross section as is seen on Bremner River and its branches. The river flows through a succession of short canyons and intervening gravel flats that occupy overdeepened basins due to ice erosion in the valley floor.

All that part of the stream to which the name Little Bremner is applied flows through slate and graywacke; but Falls Creek, a large upper tributary, heads in schist between Bremner River and Canyen Creek on the north. Toward the head of the river, near the border of the schist, numerous light-colored porphyritic dikes make their appearance. The dip of the slate cleavage, which in most places, 
though by no means everywhere, corresponds approximately with that of the bedding, is $30^{\circ}-40^{\circ} \mathrm{S}$. on the lower river, but gradually decreases toward the north.

Prospecting on the Little Bremner in 1911 was confined to the lower end of the flat between the upper canyon and the glacier from which the river flows. This flat is between 1 and 2 miles long and about a quarter of a mile wide. It was formed, as has been explained, by the filling of a shallow rock basin with outwash material from the glacier at its northwestern end. The presence of coarse gold in the gravel has been known for some years, and a small amount has been obtained by pick and shovel.

In 1911 a drill was brought in to prospect the ground in order to determine whether or not it would be profitable to install mining machinery. Three holes were put down, reaching bedrock at a depth of 47 feet after passing through 7 feet of coarse surface gravel and 40 feet of glacier mud containing rounded and angular rock fragments. Gold is reported to have been found only in the surface wash.

Conditions are favorable for placer mining at this place if the gold content of the gravel proves sufficient to encourage it. Falls Creek could furnish the water necessary for hydraulic operations, or it is believed the upper Tebay Lake could be diverted to the south side of the divide. Either would supply the necessary head. Furthermore; the Little Bremner possesses a good supply of excellent timber suitable for all ordinary mining purposes.

GOLD LODES.

Golconda Creete-Little prospecting for lode deposits has been done on Golconda Creek and in its vicinity, though the finding of gold in the same formations near Valdez has lately aroused some interest. The slate country rock is cut by numerous porphyry dikes and by less conspicuous veins of quartz or quartz and calcite. No direct connection between the intrusives and the quartz veins was proved, but they are closely associated at various places. Some of the quartz veins are mineralized, but none of them were sampled by the writer and they are not known to him to carry gold in commercial quantities. Two claims, to which the names Golconda and Mammoth were given, have been staked on the slope of the mountain north of the pass between Golconda and Monahan creeks. The slate is here intruded by several prominent dikes of fine-grained quartz monzonite porphyry and is cut by a perpendicular fault running north and south. This fault is traced with little difficulty throughout most of the length of the two claims, for the shattered slate near the fault breaks down more easily than the harder rock on each side, leaving a well-defined depression. At Discovery stake, which is on the end $28566^{\circ}-$ Bull. 576-14 -4 
line between the two claims, several hundred feet higher than the summit of the pass, a mass of quartz and calcite is cut longitudinally through its center by the fault, which thus gives evidence of movement after the vein filling was introduced. The west half of the vein consists of cavernous iron-stained quartz, but the east half is made up of calcite containing veins and crystals of quartz. This exposure of vein material is about 60 feet long. Some distance below it along the fault another lens of quartz, 6 to 8 feet thick, is associated with a fine-grained dike. The vein appears again in a little gulch above Discovery stake, but the intervening space is barren, although the fault itself is plainly seen. It is evident that the vein filling occurs in a well-defined fault fissure and that it pinches and swells markedly, so that the quartz and calcite masses take the form of lenses irregularly scattered along the fault. Pyrite and zinc sulphide are present in the vein and a small amount of gold is reported in assay returns. No work had been done on the property at the time of visit (August, 1911), so that only the surface exposures could be examined.

Bremner and Little Bremner rivers.-Claims have been staked on a number of quartz veins on the lower part of Bremner River and on the Little Bremner. Most of these veins are small, but a number reach a thickness of several feet and can be traced for some little distance on the surface. The larger veins show a slight mineralization and are reported to have yielded small amounts of gold when assayed. No development work has been done on them.

Copper River.-During the summer of 1911 a considerable number of men were engaged in prospecting on the west side of Copper River between the Chitina and the coast. Gold-bearing quartz float was found at various places and many small gold-bearing veins were discovered. A few of the veins give basis for mining projects but have not yet been opened up sufficiently to prove their value, although more or less work has been done on them.

In general, the veins are small both in thickness and in their horizontal extent. Most of them occur as stringers and lenses, but a few have been introduced along well-defined fissures. Free gold associated with sulphides, chiefly pyrite and galena, is found in many of the veins in varying amounts. Some of the small stringers are remarkably rich, but appear to be of no commercial value, being too small to be mined individually and too few to constitute a profitable stockwork.

Several properties between Chitina and Tiekel were visited by members of the Survey party, but time to visit all of them was lacking. Near the railroad, at mile 109, an adit 40 feet long had been driven to crosscut a vein of quartz that appeared in the schist on the surface above. The vein, which is 4 feet thick, strikes N. $10^{\circ} \mathrm{E}$., and dips slightly to the east, carries gold and a small amount of 
galena. A short distance to the south is another property on which assessment work has been done and which is reported to carry gold in varying amounts up to $\$ 45$ a ton.

The property of the Standard Mines Co. is on the ridge near the head of Eagle Creek, over 4,000 feet above the Copper. A shallow vertical shaft was sunk on a quartz vein in schist. The vein, which strikes north and dips slightly east, is about 13 inches thick at the surface but is a little larger below. It carries visible free gold associated with pyrite and galena. Assays of $\$ 60$ to the ton have been obtained, as well as much higher values from picked specimens. Near-by properties show the same sort of surface croppings, but carry a little chalcopyrite in addition to the sulphides.

Other gold-bearing veins nearer the coast on Copper River and in the mountains between Copper River and the Military Road have had considerable work done. on them but have not developed into mines.

\section{COPPER.}

Distribution and mode of occurrence.-A number of copper claims have been staked in the mountains between Canyon Creek and Chitina River and at the head of Cany Creek. One of them, the Blakney property, near Taral, is patented. On three or four others considerable work has been done, but on the remainder operations have been restricted to the assessment work necessary to hold the property. Most of the copper prospects are in shear zones or fractures of various kinds in greenstone and thus resemble the copper deposits of the Nikolai greenstone north of Chitina River. The only known exception to this mode of occurrence is found on Canyon Creek, where the copper minerals are associated with a dark basic dike cutting limestone and schist.

Taral Creek.-The Blakney property is near the head of Taral Creek, 5 miles east of Taral, and approximately 3,400 feet above it. Greenstone, probably derived from an original diabase intrusion or a surface flow, forms the country rock but is succeeded only a short distance to the east by diorite. The diorite is believed to be younger than the greenstone and to be intruded into it. The greenstone has been subjected to great pressure and as a result is much shattered. Locally the rock is so much crushed that it is difficult to obtain a good hand specimen. Furthermore, the rock has undergone extensive chemical alteration, which is greatest where the rock is most crushed.

At the Blakney property a fault zone, made up of numerous parallel fractures and filled with copper and iron sulphides, is exposed on the south side of the creek. The ore body consists of parallel veins of pyrite and chalcopyrite, from half an inch to 18 inches thick, separated by thin sheets of greenstone, the whole being about 3 feet 
wide. It strikes $\mathrm{N} .75^{\circ} \mathrm{W}$. and dips $45^{\circ} \mathrm{SW}$. An incline was sunk in the ore at its lowest exposure on the creek. From there the vein extends up the creek for 200 feet to a point where it is cut off by a cross fault striking $\mathrm{N} .40^{\circ} \mathrm{W}$. and dipping high to the northeast.This ore body is much larger than any other yet discovered in the vicinity of Taral and so far as the writer knows is as large as any chalcopyrite body not of a disseminated character yet found among the copper deposits of the Chitina region.

Surprise Creek.-Surprise Creek occupies one of the principal gulches on the east side of Nerelna Creek, which it joins about 2 miles from Chitina River. The bedrock is greenstone, intruded near the mouth of the creek by a great mass of diorite, but associated farther upstream with schist and much-altered siliceous limestone.

About $1 \frac{1}{2}$ miles from the mouth of Surprise Creek a short tunnel has been driven in a shattered zone in greenstone containing copper minerals. The fractures in this zone are veined with an intergrowth of quartz and epidote. Particles of chalcopyrite, pyrite, chrysocolla, chalcocite, and bornite are found in the quartz and are also disseminated through the greenstone, their relative amounts in the rock corresponding with the order named, chalcopyrite being greatest. The occurrence of these minerals is similar to that so common in the Nikolai greenstone.

Falls Creek.-Falls Creek, a tributary of Canyon Creek, rising in the mountains northwest of Summit Lake, lies mostly in a small basin more than a thousand feet above Canyon Creek, to which it descends in a succession of falls through a narrow, precipitous gulch. It is reached from the trail between Taral and Canyon creeks by a branch trail leading up Divide Creek and over the ridge between Divide and Falls creeks. In its basin greenstone is confusedly associated with altered sedimentary beds that include slate, schist, and highly siliceous thin-bedded limestone. Greenstone prevails south of Falls Creek and altered sediments north of it.

In 1911 two tunnels, one 105 and the other 150 feet long, approximately 400 feet apart, were driven in the mountain on the south side of Falls Creek, about 250 feet above the level of the camp near the creek. Specimens of ore from the longer tunnel show disseminated bornite, covellite, and chalcopyrite in greenstone.

Copper minerals are also found near the trail on the ridge between Divide and Falls creeks, where a small open cut in jointed and fractured greenstone shows chalcopyrite and bornite disseminated and as reins. Covellite and the carbonates resulting from oxidation are present in small amount.

Canyon Creek.-Canyon Creek, whose head lies in the mountains southwest of Summit Lake in the Hanagita Valley, is fed by several small glaciers leading down from the snow fields between Canyon 
Creek and Little Bremner River. In its upper courses near the main trail running past Summit Lake it flows through a narrow gravel-floored basin surrounded by high mountains of intensely folded and much-altered sedimentary beds, among which a massive limestone several hundred feet thick is conspicuous. This limestone is seen on both sides of the valley, but the bed is not continuous, having been extensively faulted, so that in places it is interrupted by schist.

Indications of copper were found about a mile south of the main valley of Canyon Creek and Summit Lake. Just at the top of the talus slope and about 500 feet above the valley floor a tunnel was driven along a copper-stained fault plane in a highly. siliceous limestone, which dips $35^{\circ}-45^{\circ} \mathrm{N}$. The fault plane strikes N. $40^{\circ} \mathrm{E}$. and dips about $45^{\circ} \mathrm{NW}$. Smaller perpendicular faults, showing slickensided rock faces nearly at right angles to the main fault, are also present but show no copper stains. A little below the tunnel a dark fine-grained dike of peridotite, cutting schist, which is probably faulted into limestone, contains pyrite or pyrite and chalcopyrite and is seemingly the source of the copper stains along the fault plane in the limestone above. It is reported that assay shows nickel as well as copper.

A large open cut and a drift 20 feet long and a trail leading to the property represented the development work done on the claim at the end of August, 1911. The owners considered this showing sufficient to justify them in expending a considerable additional sum in proving up the property and in beginning the construction of a trail down Canyon Creek to Copper River.

\section{SUMMARY.}

The known mineral resources of the Hanagita and Bremner River valleys include copper and gold.

Copper has been found only in association with altered basic igneous rocks in the vicinity of Taral. A small area extending not more than 10 miles eastward from Copper River, between Chitina River and Canyon Creek, is characterized by basic intrusives of this kind and contains all but one of the known copper lodes of the district.

Gold is found chiefly in outcrop areas of slates and graywackes that represent the eastward extension of the Valdez group. The gold is apparently derived from quartz veins cutting the slates and graywackes and in such veins is accompanied by metallic sulphides of which pyrite and galena are the most common. All the gold yet produced in the district comes from gold-bearing stream gravels for the most part derived by erosion from the neighboring country rock.

Golconda Creek is the most important gold-producing stream of the district. Its auriferous deposits are a reconcentration product 
54 GEOLOGY OF HANAGITA-BREMNER REGTON, ALASKA.

from the bench gravels into which the creek has incised its channel. Gold-bearing gravels are present also on Bremner River, on Little Bremner River, and on some other tributaries of the Bremner, but they have yielded only a small amount of gold.

An excellent supply of water for placer-mining purposes is available on many streams of the district. Timber suitable for most mining requirements is found in all the lower valleys. Transportation facilities between the Hanagita and Bremner River valleys and the coast have been greatly improved since 1910 by construction of the Copper River \& Northwestern Railway, which has reduced the cost of freighting and has made it possible to obtain mining supplies in summer as well as in winter. 


\section{INDEX.}

Access to region, means of ............... 15-16,5

Acknowledgments........................ 8

Allen, H. T., exploration by............. 43

Alluvium, occurrence and character of....... 30-31

Bremner River, description of ........... 10-11, 47 gold in . . ....................... 44,47-48,50

location of.

map showing.

map of.

Canyon Creek, copper on .............. 51,52-53

description of ....................... 11

rocks near, view of.................... 32

Carboniferous rocks, age and correlation of... 20-21 distribution and character of . ........... 18-20

history of . ........................... 37-38

intrusives in........................ 32-34

structure of ......................... $\quad 36$

Chapin, Theodore, on Quaternary deposits. . 27-32

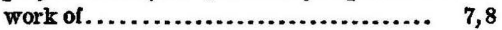

Chisna formation, distribution and character of ........................... 21

Chitina quadrangle, map of............. Pocket.

Chitina River, copper on ................. 43 course of . . . . . . . . . . . . . . . . . . . . . . 39,41-42 geology on ............................. 25-27

Cirques, glaciers in ...................... $\quad 30$

Cleavage, occurrence of ................... 36

Climate, character of ..................... 12-13

Copper, discovery of. . .................... 43,53 distribution of........................ 51-53

Copper River, basin of, map of ............ 9 course of ....................... 39,41-42 gold on. ............................ 50-51 viow on ............................. $\quad 28$

Diabase, occurrence of.................... 32-33

Diorite, occurrence of. ................. $32,33,34$

Drainage, description of . ................. 10-12

Dunes, occurrence and character of........ 31-32

Economic geologic, description of.......... 43-54

Elevations, heights of ................... 8-9

Eocene time, events in ...................... 39

Eolian deposits, occurrence and character of. 31-32

Falls Creek, copper on.................... 52

Faulting, occurrence of . .................... 36-37

Fern Creek, gold on ..................... 44

Flats, occurrence and character of......... 31

Forage, occurrence and character of......... 15

Freight, transportation of................. 16-17

Geography, description of............... 8-17

Geologic history, account of................ 37-42

Geology, description of .................. 17-37

Girty, G. H., fossils determined by .......... 20

Glacial deposits, distribution and character of 28-30

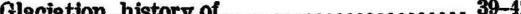
work of. $10,40-41$
Glaciers, effect of, on streams Page. effect of, on streams, figures showing..... 42

Glaciers, existing, character of ............. 30

Golconda Creek, description of.............. 45-46 gold on................. 43-44,46-47,49-50,53

Gold, discovery and development of... 43-44, 53-54 source and distribution of................ 44-45 See also Gold placers; Gold lodes.

Gold lodes, occurrence and character of... 44, 49-51

Gold placers, description of. ................ 45-49

Grant, U. S., cited ................... 23-24,25

Gravels, occurrence and character of......... 28-31

Hanagita Creek, description of.............. 11 view on ............................... 41

Hanagita Valley, description of............ 10 gold in............................ 44

location of ................... 7,8

map showing ....................... 9

map of............................ Pocket.

views in ...........................40,41

Hanging valley, view of................... 41

Historical geology, account of............. 37-42

Igneous rocks, age of....................... 35 distribution and character of......... 18, 32-35

Johnson, B. L., cited . ...................... 17, 25

Jurassic rocks, age and correlation of...... 26-27,38

distribution and character of............. 25-26

history of........................... . 38

intrusives in.......................... 34-35

figure showing................... 34

Kames, occurrence of...................... 30

Kennicott formation, intrusives in......... 35

Klu River, description of................. 11

Lakes, occurrence and character of........... 12,31 origin of ............................... 31

Little Bremner River, description of......... 48 gold on ..................... 43,44,48-49, 50

Mankomen formation, distribution and character of.......................... 21

Martin, G. C., cited......................... 17,25

Mesozoic rocks, description of.............. 22-27

subdivisions of . . . . . . . . . . . . . . . . . . . . 21-22

Mining, development of . . . ................ 43-44

Moraines, occurrence and character of........ 30

Orca group, description of . ............... 23-24

Peridotite, occurrence of. . .................. $33-34$

Population, distribution of................ 15

Precipitation, data on ..................... 12-13

Quartz monzonite, occurrence and character of ............................ 34

Quartz veins, gold in.................... 44

Quaternary deposits, distribution and charac-

ter of ..................... 18,27-32

Relief, description of . .................. 8-10

Sangaina Creek, description of............. 11 
Page.

Schrader, F. C., cited............... 20,21,37,39 Bedimentary rocks, distribution and character of

$17-32$

sequence of

figure showing.

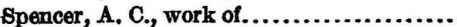

Stanton, T. W., fossills determined by .......

Streams, adjustment of. gravels on

of.................

treams, parallelism of

parallelism of, cause of

Structure, character of...

Surprise Creek, copper on.

Sunrise group, age of.

Taral, copper near.

geology near.

Taral Creek, copper on
17-18

17

7

26

27-28

28-31

10

37
$5-37$

52

17

43

36

$-52$
Page.

Tebay Lake, view of.....................

Tebay River, description of............. 11 rocks on, view of .................... 32

Temperature, data on . ................. 13

Terraces, occurrence of .................. 31

Timber, distribution of................ 13-15

distribution of, map showing............ 14

Topography, description of............. 8-12

development of..................... 38-39

Trails, location and character of . . . . . . . . 15-16

Transportation, means of................. 16-17

Valdez group, age of.................. 17, 23-25

distribution and character of........... 22-28

gold in $\ldots \ldots \ldots \ldots \ldots \ldots \ldots \ldots \ldots \ldots \ldots \ldots .44,59$

intrusives in............t............. 34

Vegetation, occurrence and character of...... 13-15 



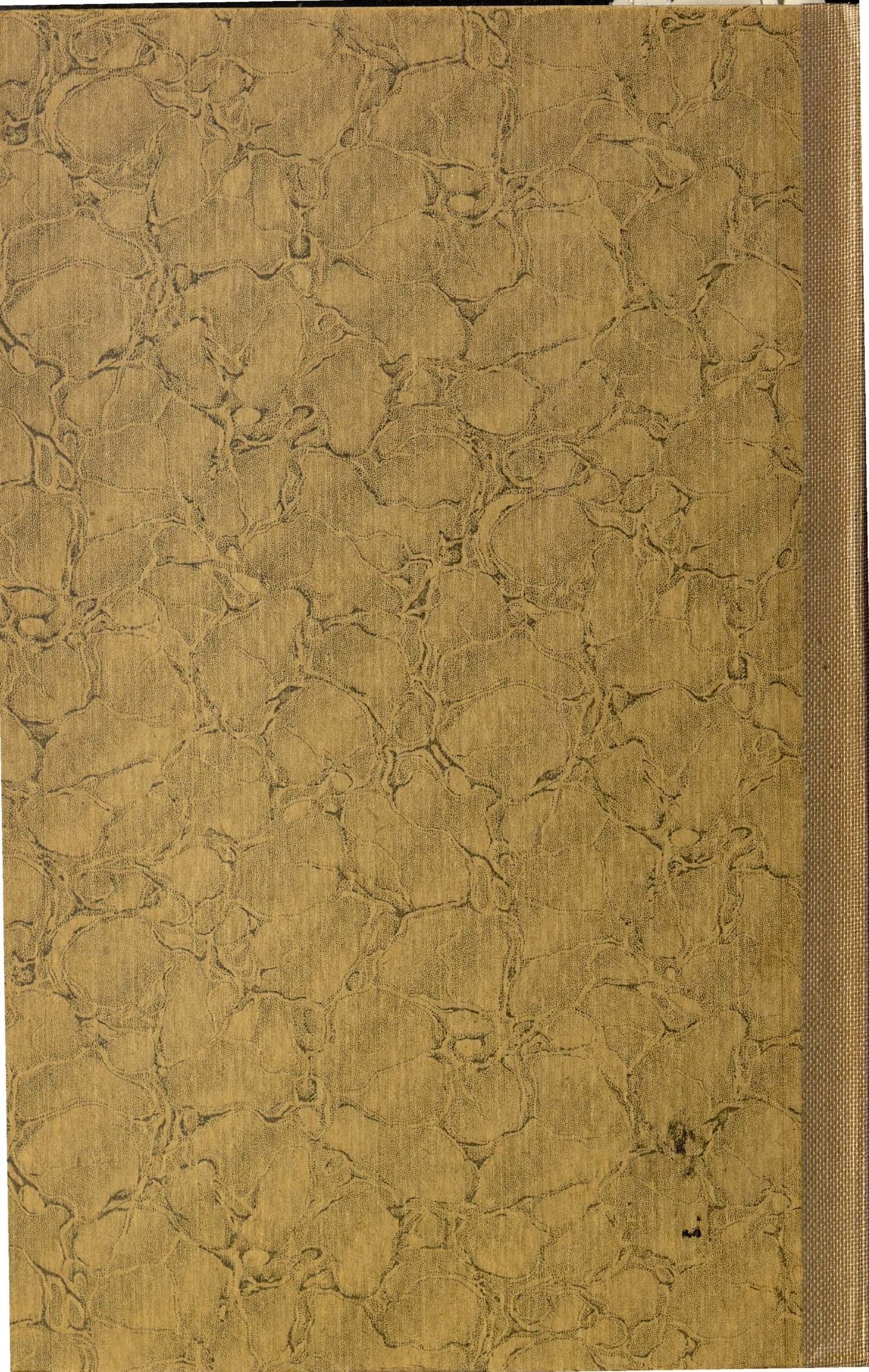

